KULTURA, RELIGIA, EDUKACJA

DOI: $10.12797 /$ Poliarchia.01.2013.01.14

Magdalena RACZYŃSKA

magdalena.raczynska@kssm.pl

\title{
OD ELITARNOŚCI DO MASOWOŚCI
}

\section{STAN SZKOLNICTWA WYŻSZEGO W POLSCE PO TRANSFORMACJI USTROJOWEJ Z 1989 R.}

ABSTRACT From elite to mass education. Diagnosis of the Polish higher education system after year 1989

Transformation that took place in 1989 in Poland paved the way for many reforms, including those in educational system. Poland became more open to Western influences, which resulted in a significant growth of the number of students and provided easier access to colleges and universities. However, nowadays (nearly 25 years later) it turns out that quantitative increase does not always entail qualitative increase. The quality of disseminated knowledge is now on a far lower level than it used to be in the $20^{\text {th }}$ century. What is more - benefits derived from having a higher education diploma are less and less perceptible. This study is an attempt to make a diagnosis of the condition of the Polish higher education after the political transformation, so it includes not only the description of positive changes but also points out all the most important imperfections.

KEYWORDS Poland, education, transformation, reform, condition

\section{WPROWADZENIE}

17 stycznia 2012 r. Związek Nauczycielstwa Polskiego przedstawił rządowi Pakt dla edukacji - obszerny dokument zawierający opracowane przez członków wyżej wymienionej organizacji propozycje dalszego rozwoju polskiej oświaty i szkolnictwa wyższego $^{1}$. Jednym z głównych argumentów, dla których postanowiono poddać go opinii

Przedstawiona w niniejszym artykule ocena dotyczy funkcjonowania działu „szkolnictwo wyższe”, w rozumieniu art. 26 Ustawy o działach administracji rządowej. Zob. Ustawa o dziataniach admini- 
publicznej pod dyskusję, było przekonanie, że mimo tego, iż ostatnie 10 lat było dla polskiej edukacji czasem dynamicznych zmian, wciąż nie udało się osiągnąć ogólnonarodowego konsensusu co do kierunku, w jakim owe reformy powinny podążać2. Ich zdaniem obecny stan szkolnictwa wyższego i nauki $w$ Polsce jest rezultatem wieloletnich zaniedbań inwestycyjnych oraz przyjętego u progu procesu transformacji zatożenia, że edukacja ( $w$ tym szkolnictwo wyższe) i nauka powinny również w petni podlegać mechanizmom wolnorynkowym, w których wiedza i wyksztatcenie sa towarem ${ }^{3}$.

Wspomniany Pakt nie jest jednak jedynym opracowaniem wskazującym na niedoskonałości polskiego systemu kształcenia na wyższym poziomie. Obszerne diagnozy stanu szkolnictwa wyższego w Polsce wraz z głównymi celami rozwoju stanowią temat również takich dokumentów strategicznych ${ }^{4}$, jak: Strategia rozwoju szkolnictwa wyższego: 2010-2020 - Projekt środowiskowy ${ }^{5}(2009)^{6}$, Strategia rozwoju nauki w Polsce do 2015 r. (2010), Strategia Rozwoju Szkolnictwa Wyższego do 2020 r. ${ }^{8}$ (2010) czy Zatożenia do nowelizacji ustawy - Prawo o szkolnictwie wyzszym oraz ustawy o stopniach naukowych i tytule naukowym oraz o stopniach i tytule w zakresie sztuki ${ }^{9}$ (2010).

Poniższą pracę poświęcono przede wszystkim przedstawieniu wielowątkowych, pochodzących z różnych źródeł (sformułowanych przez różne podmioty) oraz szczegółowych ocen różnych aspektów działania szkolnictwa wyższego w Polsce. W związku z tym wnioski - wysuwane zarówno w wymienionych dokumentach, jak i w wielu innych - zostaną selektywnie rozwinięte w dalszych punktach pracy. Wszystkie one

stracji rzadowej z dnia 4 września 1997, Dz. U. 1997, nr 141, poz. 943, [online] http://isap.sejm.gov. pl/DetailsServlet?id=WDU19971410943, 30 XI 2012.

2 Pakt dla edukacji, [online] http://www.znp.edu.pl/element/1156/Pakt_dla_edukacji, 29 XI 2012.

3 Obszar IV Paktu dla edukacji - Szkolnictwo wyższe i nauka, Związek Nauczycielstwa Polskiego, Warszawa 2011, s. 31, [online] http://www.znp.edu.pl/element/1156/Pakt_dla_edukacji, 30 XI 2012.

$4 \quad$ Więcej: Miejsce strategii nauki i szkolnictwa wyższego w systemie dokumentów strategicznych, [online] http://www.nauka.gov.pl/nauka/polityka-naukowa-panstwa/dokumenty-strategiczne/, 30 XI 2012.

5 Strategia rozwoju szkolnictwa wyższego: 2010-2020 - Projekt środowiskowy, [online] http://www.frp. org.pl/pliki/Strategia_tom-1.pdf, 30 XI 2012.

6 Daty podane w nawiasach informują, w którym roku zostały opublikowane poszczególne dokumenty strategiczne.

7 Strategia rozwoju nauki w Polsce do 2015 r., Biuletyn Informacji Publicznej, [online] http://www.bip. nauka.gov.pl/_gAllery/20/48/2048/20070629_Strategia_Rozwoju_Nauki_w_Polsce_do_2015. pdf, 30 XI 2012.

$8 \quad$ Strategia Rozwoju Szkolnictwa Wyższego do 2020 r., Oficjalna strona internetowa Ministerstwa Nauki i Szkolnictwa Wyższego, [online] http://www.nauka.gov.pl/finansowanie/fundusze-europejskie/ program-operacyjny-kapital-ludzki/projekty-systemowe/strategia-rozwoju-sw-do-roku-2020/, $30 \mathrm{XI}$ 2012.

9 Zatożenia do nowelizacji ustawy - Prawo o szkolnictwie wyższym oraz ustawy o stopniach naukowych i tytule naukowym oraz o stopniach i tytule $w$ zakresie sztuki, Biuletyn Informacji Publicznej, [online] http://www.bip.nauka.gov.pl/_gAllery/69/70/6970/20091019_Zalozenia_do_nowelizacji_ustawy. pdf, 30 XI 2012. 
sprowadzają się do tezy, że choć w ciągu ostatnich dwóch dekad niewątpliwie udało się osiągnąć wiele, to szkolnictwo wyższe wciąż wymaga wdrożenia wielu reform uwzględniających wszelkie uwarunkowania (finansowe, prawne, kulturowe, demograficzne czy społeczno-gospodarcze) mające pośredni lub bezpośredni wpływ na jego rozwój.

\section{EWOLUCJA SYSTEMU SZKOLNICTWA WYŻSZEGO W POLSCE OD POCZĄTKU XX W.}

\subsection{Uwarunkowania prawne}

Okres transformacji systemowej to dla szkolnictwa wyższego w Polsce czas szczególny - właśnie wtedy w znacznym stopniu upowszechnił się dostęp do studiów wyższych, co wyrażało się m.in. we wzroście liczby studentów oraz uczelni. Dążenie do zwiększenia dostępu do edukacji wyższej oraz zmiany dotychczas elitarnej natury uniwersytetów narastały jednak już od końca II wojny światowej. Trzeba przy tym pamiętać, że do lat 60. XX w. uchwalane ustawy swoimi zapisami podporządkowywały w pewnym stopniu szkolnictwo wyższe i naukę władzy socjalistycznej. Przykładowo Ustawa z dnia 15 grudnia 1951 r. o szkolnictwie wyższym i pracownikach nauki w art. 1 we wprowadzeniu do przepisów wstępnych wskazuje wprost na rolę szkolnictwa wyższego w ksztaltowaniu i wychowywaniu kadry inteligencji ludowej $w$ duchu ofiarnej stużby ojczyźnie, walki o pokój $i$ socjalizm ${ }^{10}$. Zakres autonomii uczelni wyższych wielokrotnie ulegał zmianom, w zależności od panującej sytuacji politycznej - w 1958 r. przywrócono (w ograniczonym stopniu) szkołom wyższym autonomię ${ }^{11}$, by 10 lat później ponownie je ograniczyć1 ${ }^{12}$. Zwiększenie (lecz wciąż nie całkowite przywrócenie) autonomii szkół wyższych miało de facto miejsce dopiero na początku lat 80. XX w., na mocy Ustawy $z$ dnia 4 maja 1982 r. o szkolnictwie wyższym (uchylonej dopiero 27 września 1990 r.) ${ }^{13}$, dzięki wskazaniu, że szkoty wyższe w swojej dziatalności kieruja się zasadami wolności nauki i sztuki, choć w dalszym ciągu sąpaństwowymi jednostkami organizacyjnymi, po-

10 Ustawa z dnia 15 grudnia 1951 r. o szkolnictwie wyższym i o pracownikach nauki, Dz. U. 1952, nr 006, poz. 38, [online] http://isap.sejm.gov.pl/DetailsServlet?id=WDU19520060038, 29 XI 2012.

11 Ustawa z dnia 5 listopada 1958 r. o szkotach wyższych, Dz. U. 1958, nr 68, poz. 336, [online] http:// isap.sejm.gov.pl/DetailsServlet?id=WDU19580680336, 29 XI 2012.

12 Ustawa z dnia 20 grudnia 1968 r. o zmianie ustawy o szkolnictwie wyższym, Dz. U. 1968, nr 46, poz. 334, [online] http://isap.sejm.gov.pl/DetailsServlet?id=WDU19680460334, 29 XI 2012. Zgodnie $\mathrm{z}$ art. 21a przy rektorze tworzono specjalne kolegium rektorskie szkoły, które miało na celu głównie udzielanie pomocy przy kierowaniu szkołą (w rozumieniu ustawy „szkoła” oznacza „szkoła wyższa”), w skład którego mieli wchodzić: rektor, prorektor, dyrektor administracyjny, sekretarz komitetu uczelnianego Polskiej Zjednoczonej Partii Robotniczej oraz przewodniczący zakładowej organizacji związkowej. Również i ta ustawa nie jest wolna od nawiązań do panującego systemu politycznego - art. 1 mówi wprost, iż szkoty wyższe aktywnie uczestnicza w budowaniu socjalizmu w Polsce Ludowej [...].

13 Ustawa z dnia 4 maja 1982 r. o szkolnictwie wyższym, Dz. U. 1982, nr 14, poz. 113, [online] http:// isap.sejm.gov.pl/DetailsServlet?id=WDU19820140113, 29 XI 2012. 
wotanymi do prowadzenia badań naukowych, ksztatcenia $i$ socjalistycznego wychowania studentów zgodnie z Konstytucją Polskiej Rzeczypospolitej Ludowej ${ }^{14}$.

Można zaryzykować stwierdzenie, że wzajemne przeplatanie się represji oraz względnej swobody dydaktyczno-badawczej to cecha charakterystyczna okresu PRL ${ }^{15}$. Jednak dopiero późniejsze wydarzenia wywołały (dającą się zaobserwować również w Polsce) bezprecedensową zmianę percepcji roli wiedzy i, co za tym idzie, szkół wyższych w życiu gospodarczym i społecznym państwa. Przekształceniu uległy także oczekiwania co do potencjalnych korzyści wynikających z tytułu uczestnictwa w edukacji na poziomie wyższym. Impulsy rozwojowe, jakich dostarczyła transformacja ustrojowa (otwarcie na globalne wpływy, nowy układ społecznych struktur czy nawet konieczność zrewidowania dotychczasowych kierunków rozwoju gospodarki), sprawiły, że rok 1989 stał się punktem zwrotnym dla instytucji edukacyjnych ${ }^{16}$. Pod naporem rosnących oczekiwań młodego pokolenia względem poziomu wykształcenia kolejne rządy podejmowały próby reformowania szkolnictwa wyższego. Najbardziej kluczowe w tej materii (głównie ze względu na fakt uwolnienia uczelni od dotychczasowego nadzoru politycznego) były dwa akty prawne z 1990 r. stanowiące pokłosie reformy nauki i szkolnictwa wyższego, przyjęte przez rząd Tadeusza Mazowieckiego ${ }^{17}$. Uchwały te stanowiły podstawę do dalszych zmian funkcjonowania uczelni wyższych oraz, w późniejszym czasie, ich dywersyfikacji. Ustawy z $1990 \mathrm{r} \cdot{ }^{18}$ zakładały bowiem podział uczelni jedynie na państwowe i prywatne ${ }^{19}$, dopiero Ustawa $z$ dnia 26 czerwca 1997 r. o wyzszych szkotach zawodowych ${ }^{20}$ wprowadziła zróżnicowanie na uczelnie niepaństwowe działające na podstawie ustawy z 1990 r. oraz niepaństwowe szkoły zawodowe. Szerzej temat ten zostanie omówiony w podrozdziale 3.3. Faktem pozostaje jednak, że wizje zmian wy-

14 Tamże, art. 1.1, art. 2.3.

15 Więcej: B. Krauz-Mozer, P. Borowiec, P. Ścigaj, Kim jesteś, politologu? Historia i stan dyscypliny, t. 1, Kraków 2011, s. 150-152.

16 K. Szafraniec, Mtodzi 2011, red. nauk. M. Boni, Warszawa 2011, s. 89.

17 Mowa tutaj o Ustawie $z$ dnia 12 września 1990 r. o szkolnictwie wyższym (Dz. U. 1990, nr 65, poz. 385, [online] http://isap.sejm.gov.pl/DetailsServlet?id=WDU19900650385, 29 XI 2012) oraz Ustawie z dnia 12 września 1990 r. o tytule naukowym i stopniach naukowych (Dz. U. 1990, nr 65, poz. 386, [online] http://isap.sejm.gov.pl/DetailsServlet?id=WDU19900650386 (29 XI 2012). Więcej: Zatożenia do aktów prawnych dotyczacych nauki, szkolnictwa wyższego i dziatalności badawczo rozwojowej (opracowanie z grudnia 1989), „Nauka Polska. Jej potrzeby, organizacja i rozwój” 1993, s. 9-26.

18 Zgodnie z art. 1 Ustawa z 12 września 1990 r. o szkolnictwie wyższym nie miała jednak zastosowania w przypadku: wyższych szkół wojskowych, wyższych szkół zawodowych, szkół wyższych i wyższych seminariów duchownych (z wyjątkiem Katolickiego Uniwersytetu Lubelskiego lub gdy Ustawy albo umowy między Rządem a właściwymi władzami Kościoła katolickiego lub właściwymi władzami innych kościołów i związków wyznaniowych stanowiły inaczej). Ustawa mogła być stosowana w odniesieniu do niepaństwowych szkół wyższych jedynie pod warunkiem, że jej przepisy lub przepisy innych ustaw nie stanowily inaczej.

19 Określenia „państwowa” oraz „prywatna” w odniesieniu do szkół wyższych zniosła dopiero Ustawa z dnia 27 lipca 2005 r. Prawo o szkolnictwie wyższym, zastępując je określeniami „publiczna” oraz „niepubliczna", natomiast kryteria różnicowania tych szkół nie uległy zmianie.

20 Ustawa z dnia 26 czerwca 1997 r. o wyższych szkotach zawodowych, Dz. U. 1997, nr 96, poz. 590, [online] http://isap.sejm.gov.pl/DetailsServlet?id=WDU19970960590, 29 XI 2012. 
suwane przez kolejne rządy nie zawsze odnajdywały odzwierciedlenie w rzeczywistości, co może obecnie sugerować, że prace nad modyfikacją szkolnictwa wyższego były chaotycznie i wewnętrznie niespójne.

Obecnie szkolnictwo wyższe i nauka funkcjonują pod rządami ustawy Prawo o Szkolnictwie Wyższym z dnia 27 lipca 2005 roku ${ }^{21}$. Kształtuje ona zarówno zewnętrzny ład akademicki, jak i elementy ładu wewnętrznego ${ }^{22}$, określa również m.in.: zasady organizacji i działania szkół wyższych, tryb ich tworzenia i likwidacji, kompetencje nauczycieli akademickich i innych pracowników uczelni, a także kompetencje takich instytucji, jak Polska Komisja Akredytacyjna czy Rada Główna Nauki i Szkolnictwa Wyższego.

Oprócz wymienionych wyżej ustaw podstawowymi zewnętrznymi uwarunkowaniami prawnymi dla rozwoju szkolnictwa wyższego są postanowienia Konstytucji RP z 2 kwietnia 1997 r. $^{23}$ oraz wiążące Polskę normy prawa międzynarodowego, w tym prawo Unii Europejskiej (mające wpływ na funkcjonowanie szkół wyższych głównie w kwestiach związanych z pozyskiwaniem unijnych środków na badania i działalność dydaktyczną), oraz ratyfikowane przez Polskę umowy międzynarodowe ${ }^{24}$.

\subsection{Funkcje szkolnictwa wyższego}

Funkcje szkolnictwa wyższego ewoluowały od lat 90. ubiegłego wieku²5. Od czasu wprowadzenia w Polsce w 1989 r. struktur demokratycznych rozwijał się proces re-

21 Ustawa z dnia 27 lipca 2005 r. Prawo o szkolnictwie wyższym, Dz. U. 2005, nr 164, poz. 1365, [online] http://isip.sejm.gov.pl/DetailsServlet?id=WDU20051641365, 30 XI 2012.

22 Poprzez ład winno się rozumieć sposób, w jaki sprawujący władzę wdrażają decyzje i założenia polityczne dotyczące życia publicznego. Analogicznie, ład akademicki dotyczy procesów i rozwiązań organizacyjnych regulujących funkcjonowanie szkolnictwa wyższego. Ład akademicki zewnętrzny jest związany z władzą publiczną oraz otoczeniem społecznym uczelni, natomiast ład akademicki wewnętrzny określa uwarunkowania oraz mechanizmy działania uczelni. Więcej na temat ładu akademickiego zob. Diagnoza stanu szkolnictwa wyższego w Polsce. Organizacyjna i merytoryczna koordynacja procesu opracowania projektów sektorowej strategii rozwoju szkolnictwa wyższego w roku 2020, ze szczególnym uwzględnieniem okresu do 2015 roku, Ernst \& Young Business Advisory, Instytut Badań nad Gospodarką Rynkową, listopad 2009, s. 10-26.

23 W większości przypadków Konstytucja RP jedynie sygnalizuje najważniejsze kwestie związane ze szkolnictwem wyższym, zezwalając równocześnie na ich późniejsze doprecyzowanie w ustawie. Dotyczy to głównie art. 70 ust. 2 mówiącego o bezpłatności nauki w szkołach publicznych, art. 70 ust. 5 zapewniającego autonomię szkół wyższych (na zasadach określonych w ustawie). Z kolei art. 70 ust. 4 nakłada na władze publiczne obowiązek zagwarantowania swoim obywatelom powszechnego i równego dostępu do wykształcenia. Zob. Uwarunkowania rozwoju szkolnictwa wyższego: prawo, finanse publiczne, czynniki kulturowe, przygotowanie absolwentów, Ernst\&Young Business Advisory, Instytut Badań nad Gospodarką Rynkową, listopad 2009, s. 5-6, [online] http://www.nauka.gov.pl/fileadmin/user_upload/Finansowanie/fundusze_europejskie/PO_KL/Projekty_systemowe/20100727_Etap_2_uwarunkowania_rozwoju_SW_prawo_finanse_publiczne_czynniki_kulturowe_przygotowanie_absolwentow.pdf, 30 XI 2012.

24 Tamże.

25 Polski system edukacji po reformie 1999 roku. Stan, perspektywy, zagrożenia, red. nauk. Z. Andrzejak, L. Kacprzak, K. Pająk, Poznań-Warszawa 2005, s. 31. 
form, stopniowo obejmujący wszystkie obszary życia, którego głównym celem stało się gruntowne zreformowanie edukacji. Koncepcja przekształcenia polskiego systemu oświatowego opierała się na trzech zasadniczych pryncypiach:

- decentralizacja (jak wspomniano, rok 1990 oznaczał koniec obowiązywania monopolu władzy centralnej w kształtowaniu oświaty);

- demokratyzacja (zarówno w kontekście systemu zarządzania, jak i określenia ideałów edukacyjnych promujących pluralistyczne myślenie);

- utylitaryzm (wykorzystanie kształcenia dla rozwoju kreatywnych i elastycznych osobowości z wiedzą zgodną z najwyższymi oczekiwaniami) ${ }^{26}$.

Transformacja ustrojowa z 1989 r. sprawiła, że Polska przeszła z elitarnego szkolnictwa wyższego do jego etapu masowego ${ }^{27}$. Proces ten implikuje zjawiska o charakterze zarówno pozytywnym, takie jak wzrost liczby uczelni wyższych oraz uczęszczających do nich studentów, jak i negatywnym, których koronnym przykładem jest dający się zaobserwować spadek jakości kształcenia czy niedostosowanie oferty edukacyjnej do wymogów rynku pracy. Analiza każdej ze zmian w szkolnictwie wyższym pokazuje równocześnie, że ich ostateczna ocena może być różna, w zależności od przyjętych kryteriów. Dlatego też nie można określić bilansu dostosowania systemu edukacji do oczekiwań zgłaszanych przez młode pokolenia jako jednoznacznie pozytywnego. Jednak niewątpliwie udało się osiągnąć wiele. Zastosowana w niniejszym artykule ocena wybranych przemian, jakie zaszły w omawianych okresie w szkolnictwie wyższym, jako pozytywne lub negatywne odbywała się głównie w oparciu o kryterium wpływu na jakość kształcenia, definiowaną obecnie przez jego efekty ${ }^{28}$.

\subsection{Ocena jakości kształcenia na uczelniach wyższych}

Wraz z rozwojem szkolnictwa wyższego presja na ocenę jakości funkcjonowania szkół wyższych zaczęła przybierać formy nie tylko oceny wewnętrznej, przeprowadzanej przez konkretne instytucje głównie w celu samodoskonalenia, ale także zewnętrznej, stanowiącej niejako element społecznej kontroli nad jakością ${ }^{29}$. Aby zapewnić możliwie jak najwyższą jakość kształcenia w warunkach jego masowości, powstało wiele orga-

26 Szkota i pedagogika w dobie przetomu, red. T. Lewowicki, S. Mieszalski, M.S. Szymański, Warszawa 1995, s. 204

27 Na potrzeby niniejszej pracy autorka posługuje się określeniami „elitarny” oraz „masowy” w odniesieniu do łatwości dostępu do szkolnictwa wyższego oraz, w efekcie, liczby korzystających z prawa do edukacji na wyższym poziomie studentów. Por. definicja słowa „masowy”: 'obejmujący dużą liczbę jednostek lub dużą ilość czegoś, przeznaczony dla szerokiego ogółu, dla mas ludzkich' (Stownik języka polskiego, t. 2, Warszawa 1988, s. 119.

28 Por. Strategia rozwoju szkolnictwa wyższego 2010-2020. Projekt środowiskowy, s. 25, [online] http:// www.krasp.org.pl/pl/strategia/strategia, 29 XI 2012. Strategia została przyjęta 6 maja 2010 r. na posiedzeniu Zgromadzenia Plenarnego Konferencji Rektorów Akademickich Szkół Polskich (KRASP) w Kielcach.

29 Analiza strategii, modeli dziatania oraz ścieżek ewolucji wiodaccych szkót wyższych na świecie, raport z badania przeprowadzonego w ramach projektu „Akademickie Mazowsze 2030”, Warszawa 2010, s. 101 . 
nizacji zajmujących się oceną (w późniejszym czasie - akredytacją ${ }^{30}$ ) polskich uczelni wyższych publicznych i niepublicznych według wcześniej określonych, jasnych i możliwie jak najbardziej obiektywnych kryteriów.

De facto akredytacja pojawiła się w Polsce w pierwszej połowie lat 90. w wyniku współpracy wielu szkół wyższych (państwowych i niepaństwowych) z partnerami zagranicznymi, którymi były głównie uczelnie ze Stanów Zjednoczonych oraz Wielkiej Brytanii ${ }^{31}$. 4 lipca 1994 r. Stowarzyszenie Edukacji Menedżerskiej „Forum” (SEM „Forum”) doprowadziło do podpisania Porozumienia Szkół Biznesu na rzecz Jakości Kształcenia, stanowiącego formalną podstawę do utworzenia pierwszego w Polsce środowiskowego systemu akredytacyjnego ${ }^{32}$.. Kolejne lata przyniosły szereg inicjatyw środowiskowych i komisji akredytacyjnych; obecnie największe z nich to: Uniwersytecka Komisja Akredytacyjna (akredytacje czasowe na okres 2 do 5 lat ${ }^{33}$ ), Komisja Akredytacyjna Uczelni Medycznych ${ }^{34}$, Fundacja Promocji i Akredytacji Kierunków Ekonomicznych ${ }^{35}$ oraz Komisja Akredytacyjna Uczelni Technicznych ${ }^{36}$. Największe i najważniejsze pozostają jednak Rada Główna Nauki i Szkolnictwa Wyższego ${ }^{37}$, współdziałająca m.in. z ministrem właściwym ds. nauki i szkolnictwa wyższego, oraz Polska Komisja Akredytacyjna ${ }^{38}$, współpracująca z innymi komisjami akredytacyjnymi

30 Akredytacja to proces, podczas którego określa się, czy i w jakim stopniu program edukacyjny (bądź zgłaszająca się uczelnia) spełnia ustanowione przez agendę akredytacyjną kryteria jakości, które mają gwarantować poziom kształcenia uznany powszechnie za satysfakcjonujący. Efektem akredytacji jest opinia na temat tego, czy program/uczelnia spełnia progowe standardy jakości. Więcej: B. Macukow, Akredytacja i jakość, [online] http://forumakademickie.pl/fa/2011/11/akredytacja-i-jakosc/, 1 XII 2012.

31 M. Bielski, Nie akt, lecz proces, [online] http://forumakad.pl/archiwum/2001/11/artykuly/06-sem forum.htm, 1 XII 2012.

32 Akredytacja środowiskowa, Portal o jakości w szkolnictwie wyższym, [online] http://www.mea-universitas.pl/akredytacja-srodowiskowa/, 1 XII 2012.

33 Uniwersytecka Komisja Akredytacyjna (UKA) powstała 18 października 1997 r. na mocy Porozumienia Uniwersytetów Polskich na rzecz Jakości Kształcenia, nowelizowanego następnie 11 października 1999 r. oraz 4 listopada 2005 r. Więcej: http://uka.amu.edu.pl/uka_main.php, 1 XII 2012.

34 Komisja Akredytacyjna Akademickich Uczelni Medycznych (KAAUM) została powołana uchwałą Konferencji Rektorów Akademickich Uczelni Medycznych (KRAUM), obradującej w Gdańsku 7 października 1997 r. Strona internetowa KRAUM: http://www.kaaum.pl/.

35 Fundacja Promocji i Akredytacji Kierunków Ekonomicznych została powołana aktem podpisanym na posiedzeniu Konferencji Rektorów Uczelni Ekonomicznych 9 grudnia 2000 r. z inicjatywy pięciu państwowych uczelni ekonomicznych. Od 2004 r. Fundacja posiada status organizacji pożytku publicznego. Strona internetowa Fundacji: http://www.fundacja.edu.pl/.

36 Komisja Akredytacyjna Uczelni Technicznych (KAUT) została powołana przez Konferencję Rektorów Polskich Uczelni Technicznych 17 lutego 2001 r. w Opolu. Strona internetowa KAUT: http://www.kaut.agh.edu.pl/.

37 Zakres dziatania RGNiSW, [online] http://www.rgnisw.nauka.gov.pl/?q=node/657, 1 XII 2012.

38 Na mocy przepisów ustawy z 18 marca 2011 r. o zmianie ustawy Prawo o szkolnictwie wyższym, ustawy o stopniach naukowych i tytule naukowym oraz o stopniach i tytule $w$ zakresie sztuki oraz o zmianie niektórych innych ustaw (Dz. U. 2011, nr 84, poz. 455) Państwowa Komisja Akredytacyjna z dniem 1 października 2011 r. stała się Polską Komisją Akredytacyjną. Tekst ogłoszony wraz z tekstem ujednoliconym: http://isap.sejm.gov.pl/DetailsServlet?id=WDU20110840455, 2 XII 2012. 
oraz grupującymi je organizacjami międzynarodowymi przy budowie Europejskiego Obszaru Szkolnictwa Wyższego ${ }^{39}$.

\section{ZMIANY W SZKOLNICTWIE WYŻSZYM PO 1989 R.}

\subsection{Wzrost liczby studentów}

Jednym z kluczowych czynników, który wpłynął na znaczący rozwój polskiego szkolnictwa wyższego po przemianach społeczno-gospodarczych z końca XX w., było zjawisko wchodzenia wyżu demograficznego przełomu lat 70. i 80. w wiek studencki. Między innymi właśnie on przyczynił się do prawie pięciokrotnego wzrostu liczby studiujących, z 403,8 tys. w roku akademickim 1990/1991 do 1,8412 mln w roku akademickim 2010/2011 $1^{40}$. Zmiany te przedstawiono na wykresie $\mathrm{nr}$ 1, uwzględniając także zmieniające się proporcje pomiędzy liczbą studentów kształcących się na uczelniach publicznych (z rozróżnieniem na studia stacjonarne i niestacjonarne) oraz niepublicznych ${ }^{41}$.

Rok 2009 przyniósł odwrócenie trendu - to czas, w którym skutki niżu demograficznego lat 1990-1991 zaczynają być coraz bardziej odczuwalne. Kwestia ta została rozwinięta w opracowaniu ekspertów Instytutu Badań nad Gospodarką Rynkową oraz Ernst\&Young Business Advisory. Na podstawie prognozy na lata 2008-2035 sporządzonej przez GUS, w latach 2020-2035 liczba ludności w Polsce spadnie o ok. 1,8 mln osób (ok. 5\%), przy czym dla grupy wiekowej 18-24 lat ${ }^{42}$ spadek ten będzie wynosił

39 Proces boloński - 19 czerwca 1999 r. ministrowie edukacji z 29 krajów (w tym Polski), odpowiedzialni za szkolnictwo wyższe, podpisali Deklarację Bolońską, w której postawili sobie za cel utworzenie do 2010 roku Europejskiego Obszaru Szkolnictwa Wyższego, mającego wzmocnić mobilność studentów i pracowników naukowych oraz ułatwić uczelniom podejmowanie działań umożliwiających studentom pełny rozwój ich osobowości, a także uzyskiwanie umiejętności adekwatnych do potrzeb rynku pracy. Zob. Proces Boloński. Europejski Obszar Szkolnictwa Wyższego, [online] http://www. uj.edu.pl/documents/10172/22085/proces_bolonski.pdf, 3 XII 2012. Por. Strategia Polskiej Komisji Akredytacyjnej, [online] http://www.pka.edu.pl/index.php?page=misja, 2 XII 2012.

Obszar IV Paktu dla edukacji..., s. 33.

${ }_{41}$ Z powodu braku szczegółowych danych wykres przedstawia zsumowaną liczbę studentów stacjonarnych i niestacjonarnych uczęszczających do szkół niepublicznych. Ze względu na zmiany nazewnictwa szkół wyższych w 2005 r. (Prawo o szkolnictwie wyższym) informacje dotyczące szkół niepublicznych uwzględniają również studentów studiów zaocznych, wieczorowych oraz eksternistycznych. Wiadomo jednak, że w latach 1999-2011 liczba studentów niestacjonarnych w uczelniach niepublicznych wynosiła kolejno: 1999 r. - 299581 tys., 2000 r. -342842 tys., 2001 r. -364026 tys., 2002 r. - 379806 tys., 2003 r. -388131 r., 2004 r. -412417 tys., 2005 r. -443388 tys., 2006 r. -494108 tys., 2007 r. -523736 tys., 2008 r. -538878 tys., 2009 r. -522828 tys., 2010 r. -481932 tys., 2011 r. - 429677 tys. Dane za: http://stat.gov.pl/bdl/app/dane_podgrup.display?p_id=736791\&p_toke$\mathrm{n}=0.5528551258612424,29$ XI 2012.

42 Uwarunkowania przysztego rozwoju szkolnictwa wyższego w Polsce: globalizacja, demografia i zmiany spoteczno-gospodarcze w Polsce. Organizacyjna i merytoryczna koordynacja procesu opracowania projektów sektorowej strategii rozwoju szkolnictwa wyższego do roku 2020, ze szczególnym uwzględnieniem okresu do 2015 roku, Instytut Badań nad Gospodarką Rynkową, Ernst\&Young Business Advisory, 
ok. 130 tys. Kolejne projekcje zakładają, że w wyniku zmian demograficznych liczba studentów w Polsce spadnie z 2,118 mln w 2005 do 1,624 mln w 2015, 1,327 mln w 2020 i 1,171 mln w 2025 r. ${ }^{43}$ Takie zmiany demograficzne (przy braku zmian wśród pozostałych czynników) mogą w latach 2005-2025 skutkować spadkiem liczby studentów w Polsce aż o ok. 45\%. Przy założeniu, że system finansowania nauki i szkolnictwa wyższego nie ulegnie modyfikacji, pod znakiem zapytania stanie wówczas opłacalność utrzymywania niektórych szkół wyższych, w szczególności małych i średnich, których przychody są silnie uzależnione od intensywności prowadzonej działalności dydaktycznej. Starzenie się społeczeństwa będzie miało równocześnie znaczny wpływ na tempo wzrostu gospodarczego, jego strukturę oraz podaż i wydajność czynników produkcji, a więc zmienne wpływające bezpośrednio na warunki funkcjonowania szkolnictwa wyższego ${ }^{44}$.

Niespotykany jak dotąd przyrost liczby studentów ${ }^{45}$, do którego doszło od początku lat 90., to nie tylko efekt wyżu demograficznego, ale składowa wielu czynników, m.in.:

- rosnącej świadomości wartości (czy wręcz konieczności) wykształcenia i wiążącej się z tym presji społecznej, wywieranej w szczególności na młodsze pokolenia ${ }^{46}$;

- stale wzrastającej podaży miejsc na studiach, w latach 90. związanej bezpośrednio z polityką państwa, zgodnie z którą wysokość środków publicznych przekazywanych na rzecz uczelni była związana z liczbą kształconych przez nią studentów ${ }^{47}$;

- na początku okresu transformacji - zmiany modelu zatrudnienia wynikającej ze wzrostu zapotrzebowania na pracowników o wyższym poziomie wykształcenia ${ }^{48}$, w późniejszym okresie - chęci przesunięcia w czasie momentu wejścia

2009, s. 26, [online] http://www.nauka.gov.pl/fileadmin/user_upload/Finansowanie/fundusze_europejskie/PO_KL/Projekty_systemowe/20100727_Etap_2_uwarunkowania_rozwoju_SW_globalizacja_demografia_i_zmiany.pdf, 29 XI 2012.

43 Tamże, s. 28. Przytoczone dane pochodzą z raportu Higher Education to 2030. Na jego potrzeby przygotowano prognozy wpływu tendencji demograficznych na liczbę studentów w poszczególnych krajach OECD. Autorzy projekcji zakładali jednak, że stopa partycypacji utrzyma się na takim samym poziomie, jak w 2004 r., dlatego szacunki w liczbie studentów wskazanych w poszczególnych raportach różnią się od siebie (według danych GUS z wykresu nr 1 liczba studentów w 2005 r. nie przekroczyła nawet $2 \mathrm{mln}$ ). Zob. What Is the Impact of Demography on Higher Education Systems? A Froward-looking Approach for OECD Countries, OECD, 2008, s. 45, [online] https://www1.oecd.org/edu/ ceri/41939423.pdf, 29 XI 2012.

44 Dotyczy to w głównej mierze kwestii finansowania szkolnictwa wyższego - ograniczone możliwości zarówno ze strony środków publicznych, jak i prywatnych, wzrost kosztów publicznych „związanych z wiekiem" (ochrona zdrowia, zabezpieczenia społeczne itp.), obniżenie dynamiki PKB. Według prognoz Komisji Europejskiej z 2008 r., na skutek starzenia się społeczeństwa relacja wydatków publicznych na edukację do PKB w Polsce może obniżyć się aż z 4,7\% w 2007 r. do 3,6\% w 2020 r. Tamże, s. 34-35. Mowa tutaj również o studentach nienależących do grupy nominalnie przypisanej do poziomu kształcenia na wyższym poziomie, czego najlepszym dowodem są zmiany kolejno współczynnika skolaryzacji brutto i netto, przedstawione w punkcie 3.2. niniejszego artykułu.

M. Geryk, Rynek uczelni niepublicznych w Polsce, Warszawa 2007, s. 20.

47 B. Krauz-Mozer, P. Borowiec, P. Ścigaj, Kim jesteś, politologu?..., s. 158.

48 M. Geryk, Rynek uczelni niepublicznych..., s. 20. 
w dorosłe życie oraz konieczności rezygnacji z niezależności finansowej, co wynikało ze znacznych problemów na rynku pracy ${ }^{49}$;

- w przypadku większości uczelni - zniesienia konieczności zdawania egzaminów wstępnych na studia;

- wzrostu świadomości obywatelskiej oraz kultury demokratycznej.

Wykres 1. Liczba studentów w Polsce w latach 1990-2012 (w tys.) ${ }^{50}$

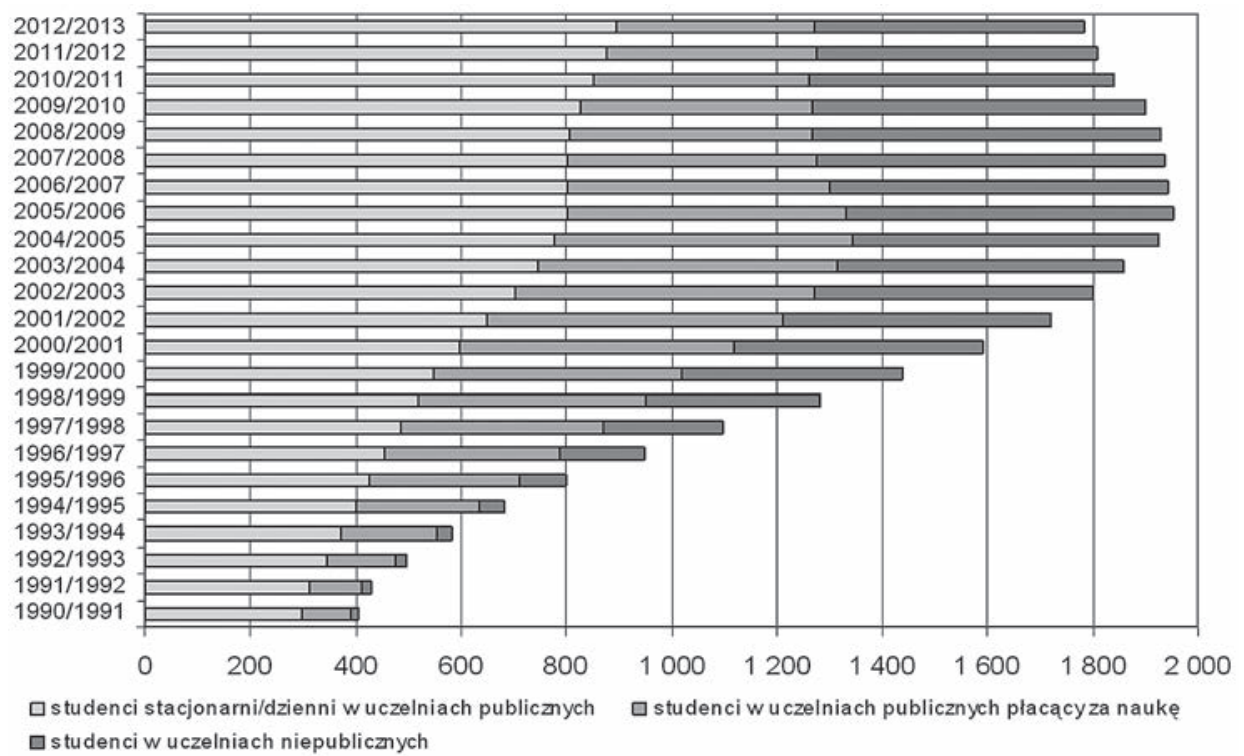

Zjawiska te spowodowały znaczny wzrost współczynnika skolaryzacji, stanowiącego miarę powszechności nauczania w danym kraju. Współczynnik skolaryzacji brutto wyraża się procentowo w stosunku wszystkich osób uczących się na danym poziomie do całej populacji osób będących w wieku nominalnie przypisywanym temu poziomowi kształcenia (na podstawie stanu z 31 grudnia określonego roku). Z kolei współczynnik skolaryzacji netto określa procentowy stosunek liczby studentów w nominalnym wieku kształcenia na danym poziomie do całej populacji osób będących w wieku przypisanym temu poziomowi kształcenia (tj. zdefiniowanych tak, jak w przypadku współczynnika brutto) $)^{51}$.

49 Na przełomie XX i XXI w., kiedy bez pracy pozostawał prawie co drugi Polak, liczba studentów na uczelniach wyższych podwoiła się. Zob.: B. Krauz-Mozer, P. Borowiec, P. Ścigaj, Kim jesteś, politologu?..., s. 158.

50 Dane według raportów GUS Szkoty wyższe i ich finanse - roczniki od 2004 do 2010 oraz materiałów na posiedzenie Sejmowej Komisji Edukacji, Nauki i Młodzieży 20 grudnia 2011 r., [w:] Obszar IV Paktu dla edukacji..., s. 33.

51 Wspótczynnik skolaryzacji - szkolnictwo wyższe, [online] http://www.studenckamarka.pl/serwis. php?s=73\&pok=1922, 29 XI 2012. 
Wykres 2. Współczynnik skolaryzacji brutto i netto w latach 1990-2010 52

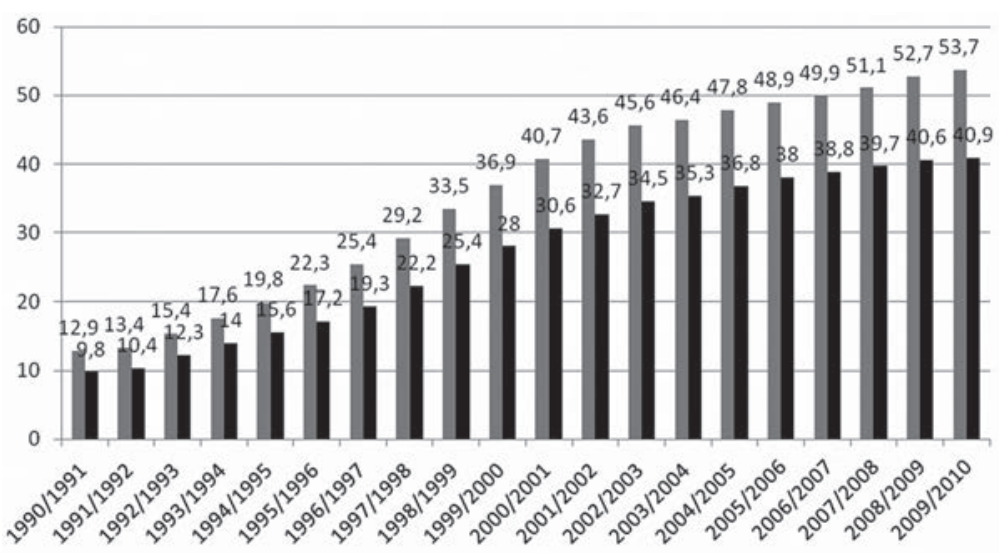

W latach $80 . \mathrm{XX}$ w. na studia wyższe przyjmowano jedynie 9-12\% młodzieży z każdego rocznika. Dawało to Polsce jedno z ostatnich miejsc w rankingach skolaryzacji wśród państw europejskich. W 2007 r. nasz kraj był już w czołówce 30 państw Organizacji Współpracy Gospodarczej i Rozwoju (OECD) ${ }^{53}$ ocenianych pod kątem wysokości wskaźnika skolaryzacji ${ }^{54}$. Paradoksalnie upowszechnienie szkolnictwa na poziomie wyższym odwraca obowiązujący paradygmat o korzystniejszej sytuacji ekonomicznej osób $\mathrm{z}$ wyższym wykształceniem w porównaniu do osób o wykształceniu średnim. W wyniku dopływu na rynek pracy ludzi o wysokich kwalifikacjach, zmienił się przeciętny poziom wykształcenia ludności Polski w wieku produkcyjnym. Pociągnęło za sobą zmniejszenie korzyści z posiadania wyższego wykształcenia (takich jak większe szanse zatrudnienia i utrzymania się na rynku pracy czy wyższe wynagrodzenie) i sprawiło, że współcześnie nie są one już tak oczywiste i odczuwalne jak jeszcze dwie dekady temu.

\subsection{Rozwój uczelni niepublicznych oraz zawodowych}

Gwałtowny rozwój szkolnictwa niepublicznego był ważnym elementem towarzyszącym upowszechnianiu studiów wyższych w Polsce ${ }^{55}$. W latach 1990-1997 szkoły niepubliczne tworzono na podstawie ustawy z 12 września 1990 r. ${ }^{56}$ Liczebność uczelni

52 Opracowanie własne na podstawie danych Głównego Urzędu Statystycznego.

53 Obecnie (stan na 2012 r.) OECD liczy już 34 członków - w 2010 r. dołączyły do niej Estonia, Izrael, Słowenia oraz Chile. Zob. List of OECD Member countries - Ratification of the Convention on the OECD, [online] http://www.oecd.org/document/58/0,3746,en_2649_201185_1889402_1_1_1_1 ,00.html, 29 XI 2012.

54 Diagnoza stanu szkolnictwa wyższego w Polsce..., s. 75.

55 Chronologicznyspisustaw regulujących funkcjonowanie szeroko pojętego szkolnictwa niepublicznego, [online] http://isap.sejm.gov.pl/KeyWordServlet?viewName=thasS\&passName=szkolnictwo $\% 20$ niepa\%C5\%84stwowe, 29 XI 2012.

56 Zob. art. 15 Ustawy o szkolnictwie wyższym z dnia 12 września 2012 r. 
wyższych publicznych i niepublicznych zrównała się już w połowie lat 90., natomiast w późniejszym okresie liczba placówek niepublicznych przekroczyła liczbę placówek publicznych. W roku akademickim 2010/2011 Polska dysponowała już 470 uczelniami wyższymi (ok. 4 razy więcej niż na początku lat 90.), z czego aż 338 z nich stanowiły uczelnie niepubliczne ${ }^{57}$ kształcące w sumie ponad 500 tys. studentów ${ }^{58}$.

Uczelnie niepaństwowe uwzględniają $\mathrm{w}$ swoich programach nauczania potrzeby nie tylko osób fizycznych (tj. studentów i kandydatów na studentów), ale także podmiotów prawnych (instytucjonalnych), stając się tym samym bardziej elastyczne na aktualne potrzeby rynku, w tym także rynku pracy. Nie tylko ułatwia to zaspokojenie indywidualnych zainteresowań studentów, dzięki uwzględnieniu ich pochodzenia środowiskowego ${ }^{59}$ oraz zdywersyfikowanej struktury wieku, ale także zmusza uczelnie publiczne do względnie systematycznego zwiększania nakładów finansowych na rozwój infrastruktury uczelnianej ${ }^{60}$. Równocześnie, jak wynika z przytoczonych wyżej danych, polskie szkolnictwo wyższe jest bardzo rozdrobnione, w związku z czym mało która placówka prywatna jest w stanie w pełni konkurować z dużymi uczelniami o uznanej renomie. W większości przypadków własna kadra wykładowców jest zbyt mała (lub składa się w większości z osób pracujących na dwóch różnych etatach), więc szkoła musi korzystać z zasobów uczelni publicznych ${ }^{61}$. Z jednej strony stwarza to pracownikom naukowym większe możliwości zarobku, z drugiej jednak wprowadza zjawisko wieloetatowości bądź wielozatrudnienia ${ }^{62}$, którego prawdopodobnym efektem może być spadek zaangażowania wykładowców w badania naukowe prowadzone przez uczelnię macierzystą, a także jakości przekazywanej przez nich wiedzy.

W specjalnym raporcie UNESCO ${ }^{63}$ wśród międzynarodowych trendów w szkolnictwie wyższym ostatniej dekady znalazło się również ukształtowanie, obok szkolnic-

57 Dane statystyczne o szkolnictwie wyższym Ministerstwa Nauki i Szkolnictwa Wyższego, [online] http:// www.nauka.gov.pl/szkolnictwo-wyzsze/dane-statystyczne-o-szkolnictwie-wyzszym/, 29 XI 2012.

58 Pod koniec 2010 r. uczelnie niepubliczne kształciły łącznie 580076 studentów. Obszar IV Paktu dla edukacji..., s. 34.

59 Więcej: Zatożenia do nowelizacji ustawy..., s. 7-8, [online] http://www.bip.nauka.gov.pl/_gAllery /69/70/6970/20091019_Zalozenia_do_nowelizacji_ustawy.pdf 30 XI 2012. Paradoksalnie, jak zauważa Mirosław Handke, z czasem uczelnie niestacjonarne, pomimo konieczności uiszczania opłat za możliwość studiowania w danej placówce, stały się rozwiązaniem idealnym dla ludzi niezamożnych i z małych miejscowości. Nie zmuszały bowiem do ponoszenia stałych kosztów związanych z utrzymaniem się w dużych ośrodkach akademickich i równocześnie ułatwiały podjęcie pracy zarobkowej w ciągu tygodnia. Zob. M. Handke, Szkolnictwo wyższe w III Rzeczpospolitej - problemy szybkiego rozwoju, „Nauka” 2000, nr 4, s. 6.

60 T. Kowalewski, Szkolnictwo wyższe na przetomie stuleci - nadzieja czy zagrożenie dla Polski?, [w:] Polski system edukacji po reformie 1999 roku..., s. 32.

${ }_{61}$ A. Matysiak (red.), Polskie szkolnictwo wyższe - stan, uwarunkowania, perspektywy, Warszawa 2009, s. 273.

62 Wieloetatowość oznacza zatrudnienie pracownika akademickiego na pełnym drugim i kolejnym etacie, podczas gdy wielozatrudnienie dotyczy dodatkowej pracy dydaktycznej prowadzonej na umowy zlecenie i umowy o dzieło.

63100 voices. A decade of inspiration and achievements in higher education, UNESCO - European Centre for Higher Education, UNESCO - CEPES, 2009, s. 23, [online] http://unesdoc.unesco.org/images/0018/001894/189471e.pdf, 1 XII 2013. 
twa akademickiego, szkolnictwa zawodowego. Wyższe szkoły zawodowe są relatywnie nowym typem uczelni. Tworzone od 1998 r. na mocy Ustawy o wyższych szkotach zawodowych z dnia 26 czerwca 1997 r.64, mają przygotowywać studentów do wykonywania konkretnych zawodów, mogąc jednak nadawać tytuły zawodowe jedynie licencjata lub inżyniera. Na szczególną uwagę zasługuje fakt, że w wielu przypadkach wyższe szkoły zawodowe powstają w miastach odległych od większych ośrodków akademickich, przyczyniając się tym samym do wyrównania szans edukacyjnych wśród ludzi z różnych środowisk ${ }^{65}$.

\subsection{Nieproporcjonalny wzrost liczby studentów w stosunku do kadry akademickiej}

Chociaż od czasów transformacji ustrojowej 1989 r. liczba polskich studentów wzrosła niemal pięciokrotnie, to liczba nauczycieli akademickich podniosła się jedynie o $60 \%{ }^{66}$. Ta dysproporcja jest szczególnie widoczna w zestawieniu z rankingami popularności kierunków studiów. Zgodnie z danymi przedstawionymi na wykresie 3, statystycznie największa liczba studentów przypada na osoby posiadające stopnie i tytuly naukowe na kierunkach z zakresu nauk społecznych, handlu oraz prawa. Równocześnie w tej grupie kierunków jest niezaprzeczalnie największy odsetek nowo przyjętych studentów, według grup kierunków studiów w Polsce i krajach OECD ${ }^{67}$.

Według wielu obserwatorów, prawdopodobnym skutkiem takiego stanu rzeczy może być spadek jakości przekazywanej wiedzy czy niemożność nawiązania przez nauczycieli akademickich bliskiego kontaktu ze studentami. Ich wzajemne relacje mogą więc coraz częściej przybierać charakter klient-sprzedawca niż uczeń-mistrz. Promowany niegdyś model nauczania, w którym wykładowca odpowiadał na pytania studentów zadawane w trakcie wykładu, aktywizując ich tym samym podczas całego cyklu zajęć, choć zgodny z założeniami Strategii Lizbońskiej, mógłby okazać się być nierealny do realizowania przy tak wysokich dysproporcjach pomiędzy liczbą studentów i nauczycieli akademickich.

Należy mieć jednak na uwadze, że zdecydowana większość danych dotyczących liczby nauczycieli akademickich jest obarczona dużym marginesem błędu. Istnieją pewne rozbieżności w publikowanych informacjach, m.in. liczba nauczycieli dydaktycznych publikowana przez GUS różni się zarówno od informacji zawartych w danych kadrowych MNiSW, jak i w danych raportowanych przez same uczelnie. Określenia faktycz-

64 Ustawa z dnia 26 czerwca 1997 r. o wyższych szkotach zawodowych, Dz. U. 1997, nr 96, poz. 590 z późn. zmianami, [online] http://isap.sejm.gov.pl/DetailsServlet?id=WDU19970960590, 1 XII 2012.

65 Szkoty wyższe $i$ ich finanse w 2010 r., Główny Urząd Statystyczny, Warszawa 2011, s. 23, [online] http://www.stat.gov.pl/cps/rde/xbcr/gus/e_szkoly_wyzsze_2010.pdf, 2 XII 2012.

66 Diagnoza stanu szkolnictwa wyższego w Polsce..., s. 82.

67 W roku akademickim 2010/2011 w Polsce prawie 50\% wszystkich nowo przyjętych studentów trafiło na kierunki z dziedziny nauk społecznych, handlu oraz prawa (36\% studentów krajów OECD), podczas gdy w przypadku drugiej w rankingu grupy, jaką są kierunki nauk humanistycznych, sztuki oraz nauk politycznych, odsetek ten wynosił jedynie 21\%. K. Szafraniec, Mtodzi 2011, s. 103. 
nej liczby etatów/osób są nieprecyzyjne, podobnie jak informacje dotyczące skali zatrudnienia w oparciu o umowy cywilnoprawne ${ }^{68}$.

Wykres 3. Liczba studentów przypadająca na nauczyciela akademickiego, osobę posiadającą stopnie dr hab. oraz tytuł naukowy profesora w Polsce w 2008 r. w zależności od grupy kierunków ${ }^{69}$

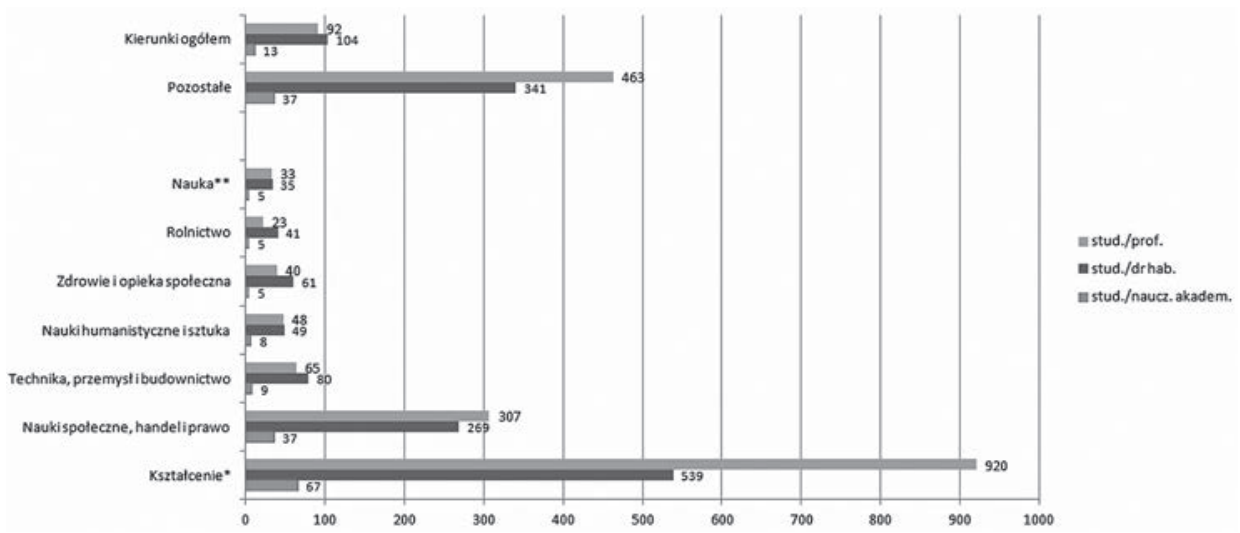

* Studia pedagogiczne.

** Grupa "nauka” obejmuje studia z zakresu biologii, biologii medycznej, inżynierii i ochrony środowiska, chemii, fizyki, geologii, oceanografii, geografii, geofizyki, matematyki i informatyki.

\subsection{Nadwyżka absolwentów o wykształceniu nieprzystającym do wymogów rynku pracy}

Zarówno w Polsce, jak i średnio w krajach Unii Europejskiej największa liczba absolwentów kończy szkoły wyższe z dyplomem kierunków z grupy „nauki społeczne, biznes i prawo" (zaliczamy do niej także marketing i zarządzanie). W Polsce absolwenci tych kierunków stanowią obecnie prawie $44 \%$ wszystkich absolwentów, podczas gdy w UE jest to ok. 35\%. Wyraźnie mniejszy jest natomiast udział absolwentów kierunków z grupy „zdrowie i opieka społeczna”: w Polsce to 9\%, a w UE - ponad 15\%, oraz kierunków związanych z techniką, przemysłem i budownictwem: w Polsce 9\%, w UE - prawie $13 \%{ }^{70}$. Warto wspomnieć, że promowanie studiów na kierunkach ścisłych i technicznych stanowi jeden z celów Strategii Lizbońskiej w obszarze edukacji ${ }^{71}$. W ostatnich latach, w wyniku wprowadzenia tzw. kierunków zamawianych, znaczą-

68 O ile w przypadku Uniwersytetu Jagiellońskiego wspomniane rozbieżności nie są znaczące, o tyle np. na Uniwersytecie Warszawskim czy Uniwersytecie im. Adama Mickiewicza w Poznaniu sytuacja wygląda o wiele bardziej niepokojąco. Więcej: Raport o stanie edukacji. Raport o stanie edukacji 2010. Spoteczeństwo w drodze do wiedzy, Warszawa 2010, s. 71.

69 Diagnoza stanu szkolnictwa wyższego w Polsce..., s. 84. Por. Tabela 4. Rozktad liczby doktorów, doktorów habilitowanych, osób posiadających tytut naukowy profesora oraz liczby studentów w latach 1994-2007, [w:] Zatożenia do nowelizacji ustawy..., s. 17.

70 Tamże, s. 74.

71 Tamże, s. 75. 
co poprawiła się struktura studentów w grupach według klasyfikacji ISCED ${ }^{72}$ przez wzrost liczby kształcących się na kierunkach dotychczas deficytowych (w roku akademickim 2010/2011 na kierunkach technika, przemysł i budownictwo studiowało 14,9\% ogółu studentów) ${ }^{73}$.

W efekcie niedostatecznego rozwoju bądź zupełnego braku systemów regularnego monitorowania losów absolwentów szkół wyższych oraz braku prognoz podaży i popytu na pracę (zarówno w kontekście zawodowym, jak i kompetencyjnym) ${ }^{74}$, oferty edukacyjne uczelni są niedostosowane do potrzeb rynku pracy. Podczas określania tych obszarów gospodarki, w których w perspektywie $5 \mathrm{czy} 10$ lat należałoby spodziewać się popytu na osoby z wyższym wykształceniem, uczelnie zdane były (i w dużej mierze wciąż są - Polska dopiero od niedawna prowadzi kompleksowe i systematyczne badania dotyczące zapotrzebowania na absolwentów uczelni różnego typu na ryn$\mathrm{ku} \mathrm{pracy}^{75}$ ) jedynie na wyniki własnych badan ${ }^{76}$. W publicznej dyskusji na temat stanu szkolnictwa wyższego coraz częściej twierdzi się, że w efekcie niedoboru stosownych narzędzi szkolnictwo wyższe na niektórych kierunkach kształcenia stało się jedynie producentem bezrobotnych absolwentów ${ }^{77}$. Niewątpliwie jest w tym wiele prawdy, co potwierdzają liczne dane statystyczne oraz wyniki konsultacji instytucjonalnych, należy jednak zachować dużą dozę krytycyzmu, aby nie paść ofiarą podstawowego błędu atrybucji ${ }^{8}$. Największym manifestem utrzymującej się nadprodukcji oraz luk w syste-

72 Międzynarodowa Standardowa Klasyfikacja Kształcenia (International Standard Classification of Education) została opracowana przez UNESCO na początku lat 70., aby służyć jako narzędzie wygodne do gromadzenia i opracowywania oraz prezentowania statystyki w zakresie edukacji zarówno w poszczególnych krajach, jak i na arenie międzynarodowej. Podstawową jednostką klasyfikacji w ISCED pozostaje program kształcenia. Programy kształcenia są definiowane na podstawie ich treści jako zestaw lub następstwo dziatań edukacyjnych, które organizuje się, by osiagnać zdefiniowany na wstępie cel lub wyspecyfikowany zestaw zadań edukacyjnych. Więcej: Europejskie a Krajowe Ramy Kwalifikacji, [online] http://siloe.slask.pl/e-portfolio/index.php?option=com_content\&view=article\&id=53:europej skie-a-krajowe-ramy-kwalifikacji\&catid=37: metodyka-eportfolio\&Itemid=50, 30 XI 2012.

73 Obszar IV Paktu dla edukacji..., s. 40.

74 W założeniu prognozy te miałyby zawierać analizy stanu i perspektyw rozwoju zasobów pracy zarówno na terytorium całego kraju, jak i na mniejszych obszarach. Powinny one dotyczyć w szczególności podażowej i popytowej strony rynku pracy, determinantów kształtowania się podaży i popytu na pracę w danym regionie oraz prognozę struktury sektorowej i zawodowo-kwalifikacyjnej popytu na pracę.

75 Badanie ewaluacyjne ex-ante dotyczace oceny zapotrzebowania gospodarki na absolwentów szkót wyższych kierunków matematycznych, przyrodniczych i technicznych, raport IBC Group na zlecenie Ministerstwa NiSzW, Warszawa 2009, s. 2.

76 Wspomniane badania i analizy są coraz częściej przeprowadzane przez stopniowo rozwijające się uczelniane Biura Karier, których podstawowym celem jest pomoc studentom w wejściu i efektywnym funkcjonowaniu na rynku pracy (głównie przez pomoc w nawiązywaniu kontaktów między nauką a przemysłem oraz promocję uczelni zarówno wśród przyszłych studentów, jak i wśród firm).

77 Obszar IV Paktu dla edukacji..., s. 40.

78 Podstawowy błąd atrybucji to pojęcie wprowadzone do psychologii społecznej przez Leo Rossa. Atrybucja zewnętrzna zakłada, że przyczyną zachowania danej osoby były właściwości sytuacji lub inne czynniki zewnętrzne względem tej osoby (np. przypadek, trudność zadania, pech), w przeciwieństwie do jej własnych cech i wyborów (np. zdolności lub ich brak, włożony wysiłek). Zob. Podstawowy btąd atrybucji, [online] http://www.naukowy.pl/encyklo.php?title=Podstawowy_b\%C5\%82\%C4\%85d_ 
mie edukacji, które doprowadziły do takiego stanu, stała się w publikacja linii radykalnej Edufactory - samoorganizacja i opór w fabrykach wiedzy, która w kategoryczny sposób neguje zaistniałe status quo w szkolnictwie wyższym na poziomie nie tylko krajowym, ale i ogólnoświatowym ${ }^{79}$.

Wykres 4 przedstawia dane Głównego Urzędu Statystycznego dotyczące zagadnienia „nadprodukcji” absolwentów wyższych uczelni, tzn. liczbę osób, którym pomimo uzyskania wykształcenia na poziomie wyższym nie udało się znaleźć pracy. Jednak do tego typu danych także nie powinno się podchodzić bezkrytycznie. O ile liczba absolwentów uczelni wyższych w określonych latach jest stosunkowo łatwa do zweryfikowania, o tyle informacja, ilu absolwentów zarejestrowanych jako bezrobotnych rzeczywiście nie podejmuje w danym czasie żadnej pracy zarobkowej, może stanowić problem. W tego rodzaju wykresach jako zarejestrowani bezrobotni uwzględniani są bardzo często również ci, którzy aktualnie odbywają staże i praktyki (niejednokrotnie płatne) za pośrednictwem Urzędu Pracy, co dodatkowo zaburza właściwą percepcję sytuacji absolwentów (również tych z poprzednich roczników) na rynku pracy.

Wykres 4. Nadprodukcja absolwentów w latach 2000-2011 $1^{80}$

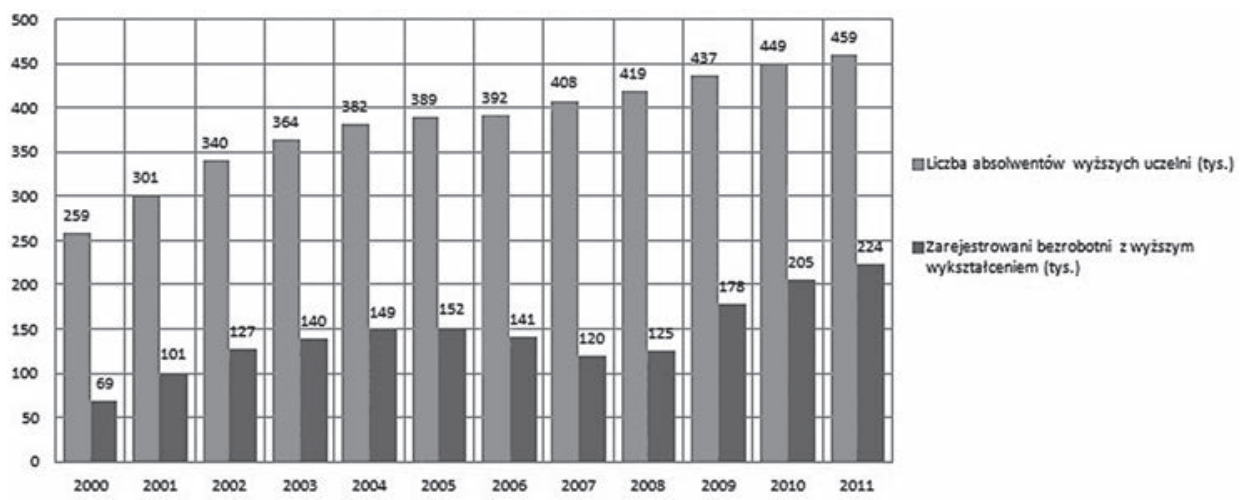

\subsection{Dewaluacja dyplomów}

Zgodnie z pierwotnymi założeniami reformy edukacji, jaka miała dokonać się po transformacji przełomu lat 80 . i 90., uniwersytety straciły swój elitarny charakter. Konsekwencją, nie do końca zamierzoną, była utrata funkcji nadawania statusu spo-

atrybucji, 1 XII 2012. W przypadku zjawiska nadprodukcji absolwentów określonych kierunków łatwo ulec przekonaniu, że niemożność znalezienia zatrudnienia mimo posiadania wykształcenia na poziomie wyższym jest jedynie skutkiem błędu systemu, a nie osoby ubiegającej się o pracę.

79 Zob. Edufactory - samoorganizacja i opór w fabrykach wiedzy, red. J. Sowa, K. Szadkowski, Kraków 2011.

80 Opracowanie własne na podstawie danych z artykułu E-learning - dobry patent na produkcję bezrobotnych, [online] http://serwisy.gazetaprawna.pl/praca-i-kariera/galerie/553495,zdjecie,1,e_learning dobry_patent_na_produkcje_bezrobotnych.html, 30 XI 2012. 
łecznego przez cały system kształcenia. W związku z nadmierną podażą wykształcenia i, co za tym idzie, nagłym nasyceniem rynku absolwentami uczelni wyższych, nastąpiła znaczna dewaluacja dyplomów (niewątpliwie jednak wielu uczelniom udało się utrzymać gwarancję jakości). Z drugiej strony, w związku z jednoczesnym wzrostem wymagań rynku, stały się one warunkiem niezbędnym do rozpoczęcia kariery zawodowej. Prowadzi to do paradoksu: dyplomy i rzekomo zdobyte w trakcie studiów kwalifikacje okazują się niewystarczające do osiągnięcia satysfakcjonującej pozycji społeczno-zawodowej - i jednocześnie są konieczne. Te same świadectwa (matura, dyplom wyższej uczelni, certyfikaty kształcenia zawodowego, szkolenia), które jeszcze na początku omawianego okresu stwarzały wysokie szanse na rynku pracy, dziś nie dają już gwarancji zatrudnienia, i to nie tylko w wyuczonym zawodzie. Opisany efekt „windy w dół” coraz częściej dotyka również absolwentów tych kierunków, które dotychczas uchodziły za gwarantujące znalezienie pracy: ekonomii czy prawa ${ }^{81}$.

Z badań przeprowadzonych w maju 2012 r. wynika, że oczekiwania pracodawców nie skupiają się obecnie wyłącznie na pozyskiwaniu absolwentów posiadających twarde, stricte zawodowe kwalifikacje ${ }^{82}$. Kluczowe dla potrzeb dzisiejszego rynku pracy wydają się raczej odpowiednio ukształtowane postawy oraz rozwinięte kompetencje miękkie, takie jak efektywna komunikacja (stopień ważności 4,6983) czy otwartość na uczenie się i stały rozwój $(4,61)^{84}$. Pracodawcy coraz wyżej cenią w młodych pracownikach te kompetencje, które można uznać za uniwersalne i oczekiwane od absolwenta szkoły wyższej, bez względu na to, jaki kierunek studiów ukończył. Obrazem tego może być fakt, że tzw. wiedza zawodowa nie znalazła się nawet w pierwszej dziesiątce zestawienia kompetencji „idealnego” absolwenta szkoły wyższej. Patrząc na najwyżej oceniane (tj. najbardziej pożądane) kwalifikacje, możemy wywnioskować, iż pracodawcy przyjmują, że absolwenci powinni mieć odpowiednio wysoki poziom wiedzy ogólnej i ogólnozawodowej, a specyficzną wiedzę kierunkową zdobędą w pracy ${ }^{85}$. Najważniejsze pozostają potencjał młodego pracownika, reprezentowana przez niego postawa (zaangażowanie - 4,57, etyka jako podstawa w działaniu - 4,47) oraz tzw. umiejętności miękkie, takie jak zdolność do pracy w zespole $(4,5)$, umiejętność określania i uzasadniania prioryte-

81 K. Szafraniec, Mtodzi 2011, s. 90.

82 Uczelnia przysztości gwarancją zatrudnienia, [online] http://pkpplewiatan.pl/opinie/stosunki_pracy/1/uczelnia_przyszlosci_gwarancja_zatrudnienia, 1 XII 2012.

83 Wszystkie wskaźniki stopni ważności wymienione w tekście podawane są w skali 1 do 5 , gdzie 1 oznacza, że dana kompetencja lub grupa kwalifikacji uznawana jest za nieważną, zaś 5 - bardzo ważną.

84 Ranking stopnia ważności kompetencji absolwentów uczelni według badanych pracodawców, [w:] Kompetencje i kwalifikacje poszukiwane przez pracodawców wśród absolwentów szkót wyższych wchodzacych na rynek pracy, wyniki badania przeprowadzonego przez Szkołę Główną Handlową w Warszawie, Amerykańską Izbę Handlu w Polsce oraz Ernst\&Young. Warszawa 2012, s. 13 i n. Metodologia badania obejmowała badanie ankietowe przeprowadzone wśród pracodawców drogą elektroniczną na platformie Survey Monkey w lutym i marcu 2012 r. oraz badania jakościowe (wywiady pogłębione z przedstawicielami pracodawców). Badaniami ankietowymi objęto około 300 firm zrzeszonych w AmCham, natomiast wywiady pogłębione zostały przeprowadzone dodatkowo z 10 osobami pełniącymi funkcje kierownicze z 7 znanych na rynku firm.

Tamże, s. 12. 
tów $(4,49)$ czy formułowania i rozwiązywania problemów $(4,4)$. Reasumując: zdaniem pracodawców uczelnia powinna przygotowywać przede wszystkim do podjęcia pracy w ogóle, nie zaś jedynie do wykonywania konkretnego zawodu, jako że wiedza stricte kierunkowa nie zawsze jest umiejętnością niezbędną do wykonywania pracy. Prowadzi to do kolejnego paradoksu obecnego w publicznym dyskursie - kierunki humanistyczne i społeczne są krytykowane za brak sukcesów w kształceniu zawodowym, podczas gdy (według badań) to właśnie wykształcenie ogólne, które te kierunki mogą zapewnić, jest obecnie najbardziej pożądane na rynku pracy.

Pomimo powyższych zestawień, a niejako na skutek efektu „windy w dół”, przekształceniu uległo podejście studentów do nauki i stylu studiowania. Wykształcenie stało się wartością instrumentalną, nie jest już celem, lecz jedynie środkiem służącym osiąganiu pozycji społeczno-zawodowej. Popularne stało się studiowanie dwóch fakultetów, wydłużył się okres nauki, wraz ze studiami doktoranckimi „na wszelki wypadek” włącznie. Pojawiła się też zupełnie nowa w historii polskiej edukacji kultura studiowania podporządkowanego CV, a wraz z nią - nowy rodzaj oczekiwań. Studenci XXI w. stają się wymagający inaczej: domagają się od krajowego systemu edukacji oferty dydaktycznej umożliwiającej pozyskanie umiejętności i wiedzy o walorach praktycznych ${ }^{86}$.

Według badań przeprowadzonych w IV edycji programu „Twoja Perspektywa” aż połowa studentów jest zdania, że zdobyte przez nich w trakcie studiów kompetencje nie przystają w żaden sposób do wymagań stawianych przez potencjalnych pracodawców. 39\% ankietowanych na pytanie: „Czy studia przygotowały Cię do podjęcia pierwszej pracy?” odpowiedziało „raczej nie”, $11 \%$ udzieliło odpowiedzi zdecydowanie negatywnej; jedynie 9\% respondentów jest usatysfakcjonowanych jakością otrzymanego na uczelni wykształcenia ${ }^{87}$. Podobnego zdania są pracodawcy. Spośród wszystkich ocenianych w badaniach kompetencji, kwalifikacji i postaw tylko jedna występuje częściej, niż jest to uznane za wymagane lub chociaż wystarczające do sprawnego funkcjonowania firmy, niezależnie od jej wielkości. Mowa o liczbie posiadanych dyplomów, certyfikatów, świadectw potwierdzających ukończenie studiów, znajomość programów czy posiadanie określonych umiejętności ${ }^{88}$.

\subsection{Niedofinansowanie szkolnictwa wyższego}

Polska należy do grupy krajów, w których obowiązuje dualny system finansowania szkolnictwa, na który składają się dotacje państwowe oraz czesne. System ten opiera się obecnie na dwóch ustawach. Pierwsza to Prawo o szkolnictwie wyższym z 27 lipca

86 K. Szafraniec, Mtodzi 2011, s. 91.

87 Potowa studentów krytycznie ocenia kompetencje zdobyte na studiach, 20 VII 2012, http://www.naukawpolsce.pap.pl/aktualnosci/news,390982,polowa-studentow-krytycznie-ocenia-kompetencje-zdobyte-na-studiach.html, 1 XII 2012. Warto pamiętać, że badania opinii i ich wyniki nie mogą stanowić podstawy do wydawania jednoznacznych osądów w kwestii realnej efektywności nauczania w szkołach wyższych. Por. Podstawowy btąd atrybucji, przypis 69.

88 Zestawienie umiejętności i wiedzy „twardej”/zawodowej: ocena vs ważność, [w:] Kompetencje $i$ kwalifikacje poszukiwane przez pracodawców..., s. 18. 
$2005 r^{89}$, określające zasady finansowania działalności edukacyjnej, druga to ustawa z 8 października 2008 r. ${ }^{90}$ normująca kwestię finansowania działalności badawczej, mówiąca o zasadach finansowania nauki ${ }^{91}$.

Wydatki z okresu transformacji przekazywane na szkolnictwo wyższe wzrosły w stosunku do PKB, jednak nieporównywalnie mniej niż liczba studentów na uczelniach. Można z tego wnioskować, że warunki finansowe edukacji wyższej w ostatnim 15-leciu nie uległy wyraźniejszym zmianom. Przy gwałtownym zwiększaniu się populacji studentów publiczne nakłady na szkolnictwo wyższe nie nadążały za nią, co skutkowało relatywnie niskimi nakładami na kształcenie w przeliczeniu na jednego studenta. W latach 90. nakłady na jednego studenta malały, ponieważ liczba korzystających z edukacji na wyższym poziomie gwałtownie rosła, a realne nakłady publiczne na edukację wyższą właściwie się nie zmieniały ${ }^{92}$. Stan chronicznego niedofinansowania utrzymuje się do dzisiaj, co wyraźnie pokazuje poniższe zestawienie.

Analizując przedstawione dane, warto zwrócić uwagę na fakt, że mimo iż środki przekazywane na utrzymanie i rozwój szkolnictwa wyższego w Polsce systematycznie rosną, ich udział w krajowym PKB maleje. Oznacza to, że poprawa takiego stanu rzeczy w ciągu najbliższych kilku lat jest raczej mało prawdopodobna. Co więcej, problematykę finansowania (lub niedofinansowania) nauki i szkolnictwa wyższego w Polsce cechuje wysoka współzależność obu tych sfer: niski poziom nakładów na badania naukowe $(B+R)$ w Polsce staje się hamulcem rozwoju szkolnictwa wyższego, a niedostateczne finansowanie szkolnictwa wyższego ${ }^{93}$ ogranicza możliwości rozwoju sektora nauki ${ }^{94}$. Co więcej, większość osób zatrudnionych w sektorze $\mathrm{B}+\mathrm{R}$ pracuje w szkołach wyższych ${ }^{95}$, co oznacza, że główny ciężar prowadzenia badań w Polsce spada de facto na szkolnictwo wyższe.

89 Prawo o szkolnictwie wyższym z 27 lipca 2005 r., Dz. U. 2005, nr 164, poz. 1365 ze zm., [online] http:// isap.sejm.gov.pl/DetailsServlet?id=WDU20051641365, 2 XII 2012.

90 Ustawa z dnia 8 października 2004 r. o zasadach finansowania nauki, Dz. U. 2004, nr 238, poz. 2390 ze zm., [online] http://isap.sejm.gov.pl/DetailsServlet?id=WDU20042382390, 2 XII 2012.

91 A. Rozmus, K. Pado, Finansowanie szkolnictwa wyższego w Polsce - wybrane dylematy i sugerowane rozwiąania, „E-finanse - finansowy kwartalnik internetowy” 2011, nr 114, s. 5, [online] http://www.e-finanse.com/artykuly_eng/114.pdf, 1 XII 2012.

92 Raport o stanie edukacji w Polsce..., s. 91.

93 W przypadku finansowania szkolnictwa wyższego mowa w głównej mierze o nakładach na dydaktykę oraz infrastrukturę uczelni, zob. M. Dąbrowa-Szefler, System nauki i szkolnictwa wyższego - funkcjonowanie i elementy zarządzania. Podręcznik, Warszawa 2003, s. 29-30.

94 Nauka obejmuje działalność sektora badawczo-rozwojowego [B+R], czyli wszelkie instytucje naukowe prowadzące badania naukowe lub prace rozwojowe, stanowiące miejsce działalności twórczej powiększającej zasób wiedzy naukowo-technicznej. Jednym z podstawowych wymogów, jakie muszą zostać spełnione, aby jednostka została zaliczona do działu B+R, jest konieczność przeznaczania minimum 10\% swojego czasu na działalność badawczo-rozwojową. Zob. M. Dąbrowa-Szefler, J. Jabłecka, Szkolnictwo wyższe w Polsce, raport dla OECD, Warszawa 2007, s. 166-167; Dziatalność badawcza i rozwojowa, [online] http://stat.gov.pl/gus/definicje_PLK_HTML.htm?id=POJ-125.htm, 1 XII 2012.

95 Udział zatrudnionych w sektorze $\mathrm{B}+\mathrm{R}$ pracujących w szkołach wyższych: 1995 r. - 68\% ogółu zatrudnionych, 2000 r. - 73\%, 2005 r-74,5\%, 2008 r. - 73,5\%. Dane za: B. Krauz-Mozer, P. Borowiec, P. Ścigaj, Kim jesteś, politologu?..., s. 170. 
Tabela 1. Wysokość wydatków publicznych na szkolnictwo wyższe w Polsce oraz PKB w latach 2000-2012 $2^{96}$

\begin{tabular}{|c|c|c|c|c|c|}
\hline \multirow[b]{2}{*}{ Lata } & \multirow[b]{2}{*}{$\begin{array}{c}\mathrm{PKB} \\
{[\mathrm{mln} \mathrm{zl}]}\end{array}$} & \multicolumn{3}{|c|}{ Nakłady na SzW [mln zt] } & \multirow[b]{2}{*}{$\begin{array}{c}\text { Udział } \\
\text { w PKB [\%] }\end{array}$} \\
\hline & & $\begin{array}{l}\text { z budżetu } \\
\text { państwa }\end{array}$ & $\begin{array}{c}\text { z budżetów } \\
\text { jednostek } \\
\text { samorządu } \\
\text { terytorialnego }\end{array}$ & $\begin{array}{c}\text { łącznie } \\
\text { ze środków } \\
\text { publicznych }\end{array}$ & \\
\hline 2000 & 744378 & 5326,7 & 20,4 & 5347,1 & 0,718 \\
\hline 2001 & 779564 & 6370,7 & 32,6 & 6403,3 & 0,821 \\
\hline 2002 & 808578 & 6829,6 & 38,6 & 6868,2 & 0,849 \\
\hline 2003 & 843156 & 7049,2 & 28,2 & 7077,4 & 0,839 \\
\hline 2004 & 924538 & 8822,3 & 31,9 & 8854,2 & 0,958 \\
\hline 2005 & 983302 & 9676,5 & 76,8 & 9753,3 & 0,992 \\
\hline 2006 & 1060031 & 9888,7 & 122,0 & 10010,7 & 0,944 \\
\hline 2007 & 1176737 & 10701,4 & 143,5 & 10844,9 & 0,922 \\
\hline 2008 & 1275432 & 11091,0 & 100,0 & 11191,0 & 0,877 \\
\hline 2009 & 1343366 & 11654,5 & 197,0 & 11851,5 & 0,882 \\
\hline 2010 & 1415400 & 11722,4 & 70,2 & 11792,6 & 0,833 \\
\hline 2011 & 1512300 & 12519,5 & 60,0 & 12579,5 & 0,832 \\
\hline 2012 & 1589600 & 12606,7 & 50,0 & 12656,7 & 0,796 \\
\hline
\end{tabular}

Wydatki publiczne na naukę i edukację, w tym także na szkolnictwo wyższe, stanowią w większości krajów OECD społeczny priorytet z zagwarantowaną wysoką pozycją w corocznych budżetach, podczas gdy w Polsce te obszary, od których zależy jej przyszłość i pozycja w Europie, pozostają od wielu lat zaniedbane ${ }^{97}$. Równocześnie pomimo, iż wydatki na polskie szkolnictwo wyższe liczone w odniesieniu do PKB zbliżone są do średniej obowiązującej w krajach OECD, ze względu na bardzo wysoką liczbę studentów poziom wydatków na studenta sytuuje szkolnictwo wyższe w Polsce na jednym z ostatnich miejsc w Europie.

Pomimo wzrostu w ostatnich dwóch latach (wynikającego z szacunkowego zaangażowania środków Funduszy Strukturalnych), środki przekazywane w Polsce na badania i rozwój są wciąż bardzo niskie - stanowią jedynie ok. 0,9\% PKB w latach 2000$-2009^{98}$ przy średniej w Unii Europejskiej na poziomie 1,9\%. W założeniach Strategii

96 Dane o wysokości PKB za lata 2000-2010 według dokumentów GUS; dane o wydatkach publicznych na szkolnictwo wyższe w Polsce w latach 2000-2010. Szkoty wyższe i ich finanse w 2010 r., tabl. 2, s. 338.

97 Obszar IV Paktu dla edukacji..., s. 31; Finansowanie uczelni publicznych, [w:] Zatożenia do nowelizacji ustawy..., s. 7-11.

98 Dane za lata 2001-2009 na podstawie: Nauka i technika w Polsce $w 2009$ roku, GUS, Warszawa 2011, tabl. 1, s. 81 oraz Nauka i technika w 2006 r., GUS, Warszawa 2007, tabl. 2, s. 32. Dane za lata 
Lizbońskiej i jej kontynuacji w postaci Strategii EUROPA 2020 (od 2010 r.) przyjęto, że wskaźnik ten ma wynosić $3 \%{ }^{99}$.

Nie wszyscy zdają sobie wciąż sprawę z faktu, że szkolnictwo wyższe i nauka stanowią najbardziej prorozwojowe we współczesnym świecie dziedziny życia społeczno-gospodarczego i to właśnie od ich koniunktury w decydującym stopniu zależy wiedza i kreatywność młodego pokolenia, a co za tym idzie - wykreowanie niezbędnych kadr, postęp technologiczno-ekonomiczny oraz innowacyjna gospodarka. Środki publiczne zainwestowane w edukację przynoszą wielorakie korzyści, widoczne między innymi w zyskach dla państwa napływających z tytułu podatków od wyższych dochodów. Według statystyk krajów OECD mężczyzna z wykształceniem wyższym w całym okresie swojej aktywności zawodowej przynosi państwu pochodzący z podatku dochodowego i składek ubezpieczeniowych dochód o 119 tys. dolarów większy niż osoba z wykształceniem średnim. Po odjęciu środków publicznych przeznaczonych na sfinansowanie kształcenia owego mężczyzny na poziomie wyższym, korzyść finansowa wyniesie średnio 86 tys. dolarów, czyli prawie trzy razy więcej niż kwota inwestycji publicznych przeznaczonych na studenta w szkolnictwie wyższym ${ }^{100}$. W Polsce stawki te są nieporównywalnie niższe, niemniej jednak zwrot wieloletnich inwestycji w edukację wciąż ma charakter odroczonej w czasie gratyfikacji ${ }^{101}$. Może ona występować zarówno w kategorii jednostkowej, tj. w formie stylu świadomego funkcjonowania w społeczeństwie i kulturze oraz obserwowanym rozwoju osobistym, jak i w kategoriach społecznych, gdzie wykształcenie wyższe przynosi korzyści cywilizacyjne, ekonomiczne oraz polityczne. Wysokie wykształcenie z założenia ma uodparniać na demagogię i manipulacje oraz sprzyjać otwieraniu się na odmienność, dzięki czemu społeczeństwo z wysokim odsetkiem ludzi wykształconych ma zdecydowanie większe szanse na dobrze zorganizowany system i cywilizacyjny rozwój ${ }^{102}$.

\subsection{Spadek jakości kształcenia}

Boom akademicki, będący skutkiem zachodzących w ostatnich latach przemian, bez wątpienia można określić jako sukces ilościowy. W toku zachodzących przeobrażeń zabrakło jednak działań, które gwarantowałyby jakościowy rozwój polskich uczel-

2010-2012 z uwzględnieniem środków funduszy strukturalnych według dokumentu Plan Rozwoju i Konsolidacji Finansów (Propozycje), Kancelaria Prezesa Rady Ministrów, 29 I 2010.

99

100

101

Obszar IV Paktu dla edukacji..., s. 38.

Edukacja w zarysie 2010: wskaźniki OECD. Podsumowanie w języku polskim, s. 2, [online] http:// www.oecd.org/education/highereducationandadultlearning/45943482.pdf, 2 XII 2012.

Wartość dodana kształcenia na poziomie wyższym w Polsce mierzona w zarobkach absolwentów szkół wyższych w relacji do średniej płacy na rynku pracy należy obecnie do jednej z najniższych w Europie - w Polsce wykształcenie na wyższym poziomie zwiększa zarobki średni o $28 \%$, podczas gdy we Francji o 64,6\%, w Portugalii o 68,8\% a w Stanach Zjednoczonych nawet o 76,8\%. Dane za: Zatożenia do nowelizacji ustawy..., s. 15.

102 K. Szafraniec, Mtodzi 2011, s. 112. 
ni oraz prowadzonych na nich zajęć dydaktycznych ${ }^{103}$. Masowość studiów, oprócz wielu zysków, przyniosła szereg niekorzystnych zjawisk, m.in. wspomniane obniżenie jakości kształcenia czy niedostosowanie oferty edukacyjnej do potrzeb rynku pracy ${ }^{104}$. W warunkach polskich problem jakości kształcenia wynika także z niedofinansowania szkolnictwa wyższego (przekazywane środki są nieadekwatne do rosnącego poziomu zadań edukacyjnych uczelni wynikającego ze wzrostu liczby studentów oraz potrzeby uruchamiania nowych kierunków) oraz wieloetatowości kadry dydaktycznej, która może (chociaż niekoniecznie musi) mieć negatywny wpływ na właściwy kontakt między studentem a nauczycielem akademickim ${ }^{105}$. Niedobór środków finansowych powoduje, że przy ograniczeniu liczby etatów uczelnie redukują liczbę godzin ponadwymiarowych, zwiększając liczebność grup projektowych, seminaryjnych i laboratoryjnych, co może prowadzić do znaczącego obniżenia efektów kształcenia. W rezultacie absolwent kończący studia często nie ma umiejętności posługiwania się sprzętem i urządzeniami będącymi na wyposażeniu u przyszłego pracodawcy ${ }^{106}$.

Nie oznacza to jednak, że aktywność analityków ogranicza się jedynie do krytyki zastanego. Coraz częściej podejmowane są w Polsce dyskusje na temat naprawy czy reformy systemu kształcenia, chociaż wysuwane podczas nich wnioski nie zawsze napawają optymizmem. Przykładem może być wypowiedź Karola Musioła, byłego rektora Uniwersytetu Jagiellońskiego: Mamy dwa aktualne problemy. Pierwszy to akceptacja przeciętności, tak $w$ dziedzinie nauczania, jak i $w$ badaniach naukowych. Drugi to zgoda na „bylejakość" $w$ dziataniu, co - w moim przekonaniu - hamuje rozwój szkolnictwa wyższego i nauki $w$ Polsce ${ }^{107}$. Polska edukacja, a dzięki niej także polska młodzież, jest w świecie zupełnie innym kulturowo i intelektualnie, niż miało to miejsce jeszcze dwie dekady temu. Nasze reformy edukacyjne, zwłaszcza te zwiększające dostępność młodzieży do lepszego i dłuższego kształcenia, spotykają się z aprobatą międzynarodowych organizacji. Znacznie gorsze oceny formułowane są jedynie pod adresem jakości kształcenia, równości szans edukacyjnych czy wzajemnego dostosowania kształcenia i rynku

103 Ewaluacja jakości dydaktyki w szkolnictwie wyższym. Metody, narzędzia, dobre praktyki, red. W. Przybylski, S. Rudnicki, A. Szwed, Kraków 2010, s. 13.

104 Nawet sztandarowe hasło „Manifestu edukacyjnego”, będącego jednym z głównym dokumentów programowych Polskiej Konfederacji Przedsiębiorców Prywatnych Lewiatan, brzmi: Czas postawić na jakość edukacji. Zob. Raport roczny 2011, Polska Konfederacja Pracodawców Prywatnych Lewiatan, Warszawa 2012, s. 47.

105 Wieloetatowość ma swoje wady i zalety. Z jednej strony pozwoliła zatrzymać w szkolnictwie publicznym kadrę, która bez pracy w drugim miejscu miałaby (w stosunku do nakładu pracy i kompetencji) bardzo niskie płace realne, w efekcie czego zapewne część z nich odpłynęłaby do innych zajęć. $\mathrm{Z}$ drugiej zaś umożliwiła prywatnym szkołom relatywnie tanie zatrudnienie nauczycieli ze szkół publicznych. Konsekwencją jednak jest, jak już wspomniano, nadmierne ilościowe obciążenie zajęciami dydaktycznymi. Niejednokrotnie odbywa się to kosztem ich jakości, choć i tak utrzymywanie standardów nauczania i zaangażowania w wykonywaną pracę na odpowiednio wysokim poziomie leży w indywidualnej gestii każdego nauczyciela, nie tylko na poziomie szkolnictwa wyższego.

106 Obszar IV Paktu dla edukacji..., s. 40.

Szkolnictwo wyższe dla innowacyjnej gospodarki, „Biuletyn Forum Debaty Publicznej” 2011, nr 1. 
pracy. Brak satysfakcjonujących rozwiązań w tych kwestiach sprawia, że marnuje się duża część potencjału intelektualnego tkwiącego w młodzieży ${ }^{108}$.

\section{ZAKOŃCZENIE}

Upowszechnienie się paradygmatu rozwojowego nazywanego gospodarką opartą na wiedzy sprzyja popularyzacji przekonania, że edukacja stanowi współcześnie niekwestionowane narzędzie służące rozwojowi jednostek. Jednak sama świadomość istoty i znaczenia szkolnictwa wyższego nie wystarcza. Przejście od elitarnego do masowego wykształcenia wyższego pociąga za sobą konieczność postawienia pytania m.in. o jego prestiż i wartość na rynku pracy. Reforma, jakiej potrzebuje dzisiaj polska edukacja na poziomie wyższym, powinna być skierowana przede wszystkim do wnętrza uczelni i szkół. Winna więc dotyczyć kwestii programowych (dostosowania ich do zmieniających się wymagań rynku pracy), metodycznych, zmieniających zasady selekcji kadr pedagogicznych i naukowych oraz, co najważniejsze, czyniących wymóg kreatywności i niekonwencjonalnego myślenia możliwie jak najbardziej naturalnym i oczywistym ${ }^{109}$. Ich dopełnieniem powinny być działania wspierające tworzenie się instytucji doradztwa zawodowego i osobistego, których sztandarowym celem byłaby pomoc młodzieży w podejmowaniu możliwie optymalnych decyzji dotyczących wyboru ścieżki edukacyjnej, kariery zawodowej oraz rozwoju osobistego, co w znaczący sposób wpłynęłoby na dostosowanie podaży (reprezentowanej przez absolwentów uczelni) do popytu (zgłaszanego przed pracodawców na rynku pracy).

\section{BIBLIOGRAFIA}

\section{Publikacje książkowe:}

Literatura pomocnicza:

- monografie i opracowania:

Dąbrowa-Szefler M., Jabłecka J., Szkolnictwo wyższe w Polsce, raport dla OECD, Warszawa 2007. Dąbrowa-Szefler M., System nauki i szkolnictwa wyższego - funkcjonowanie i elementy zarządzania. Podręcznik, Warszawa 2003.

108 K. Szafraniec, Mtodzi 2011, s. 92.

109 Reformie tej mają służyć Krajowe Ramy Kwalifikacji dla Szkolnictwa Wyższego, wprowadzone w Polsce na mocy rozporządzenia Ministra Nauki i Szkolnictwa Wyższego z dnia 2 listopada $2011 \mathrm{r}$. (Dz. U. 2011, nr 253, poz. 1520, [online] http://www.nauka.gov.pl/fileadmin/user_upload/szkolnictwo/20120110_KRK_dla_SW.pdf, 4 XII 2012). KRK stanowią całościowy opis kwalifikacji oraz ich wzajemnych współzależności, oparty na zdefiniowanych na poziomie unijnym Europejskich Ramach Kwalifikacji. Te z kolei umożliwiają efektywniejsze porównanie różnych systemów i praktyk edukacyjnych obecnych w państwach członkowskich UE, a także pozwalają uznawać kwalifikacje zdobyte w Polsce na terenie całej Unii Europejskiej, co w znacznym stopniu ułatwi kontynuowanie nauki w innych państwach. Więcej na stronie internetowej Centrum Naukowego ds. KRK: http://www.krajoweramykwalifikacji.pl/index.php?id=krk, 3 XII 2012. 
Geryk M., Rynek uczelni niepublicznych w Polsce, Warszawa 2007.

Krauz-Mozer B., Borowiec P., Ścigaj P., Kim jesteś, politologu? Historia i stan dyscypliny, t. 1, Kraków 2011.

Matysiak A. (red.), Polskie szkolnictwo wyższe - stan, uwarunkowania, perspektywy, Warszawa 2009. Stownik jezzyka polskiego, t. 2, Warszawa 1988.

Szkota i pedagogika $w$ dobie przetomu, red. T. Lewowicki, S. Mieszalski, M.S. Szymański, Warszawa 1995.

\section{- prace zbiorowe:}

Analiza strategii, modeli dziatania oraz ścieżek ewolucji wiodacych szkót wyższych na świecie, raport z badania przeprowadzonego w ramach projektu „Akademickie Mazowsze 2030”, Warszawa 2010.

Badanie ewaluacyjne ex-ante dotyczace oceny zapotrzebowania gospodarki na absolwentów szkót wyżsych kierunków matematycznych, przyrodniczych i technicznych, raport IBC Group na zlecenie Ministerstwa NiSzW, Warszawa 2009.

Ewaluacja jakości dydaktyki w szkolnictwie wyższym. Metody, narzędzia, dobre praktyki, red. W. Przybylski, S. Rudnicki, A. Szwed, Kraków 2010.

Kompetencje i kwalifikacje poszukiwane przez pracodawców wśród absolwentów szkót wyższych wchodzacych na rynek pracy, wyniki badania przeprowadzonego przez Szkołę Główną Handlową w Warszawie, Amerykańską Izbę Handlu w Polsce oraz Ernst\&Young. Warszawa 2012.

Polski system edukacji po reformie 1999 roku. Stan, perspektywy, zagrożenia, red. nauk. Z. Andrzejak, L. Kacprzak, K. Pająk, Poznań-Warszawa 2005.

Raport o stanie edukacji. Raport o stanie edukacji 2010. Spoteczeństwo w drodze do wiedzy, Warszawa 2010.

Raport roczny 2011, Polska Konfederacja Pracodawców Prywatnych Lewiatan, Warszawa 2012. Szafraniec K., Mtodzi 2011, red. nauk. M. Boni, Warszawa 2011.

\section{- rozdziały w pracach zbiorowych:}

Kowalewski T., Szkolnictwo wyższe na przetomie stuleci - nadzieja czy zagrożenie dla Polski?, [w:] Polski system edukacji po reformie 1999 roku. Stan, perspektywy, zagrożenia, red. nauk. Z. Andrzejak, L. Kacprzak, K. Pająk, Poznań-Warszawa 2005.

- artykuły w czasopismach naukowych:

Handke M., Szkolnictwo wyższe w III Rzeczpospolitej - problemy szybkiego rozwoju, „Nauka” 2000, $\mathrm{nr} 4$.

- artykuły prasowe:

Szkolnictwo wyższe dla innowacyjnej gospodarki, „Biuletyn Forum Debaty Publicznej” 2011, nr 1.

\section{Publikacje elektroniczne:}

\section{Literatura źródłowa:}

Miejsce strategii nauki i szkolnictwa wyższego w systemie dokumentów strategicznych, [online] http://www.nauka.gov.pl/nauka/polityka-naukowa-panstwa/dokumenty-strategiczne/. 
Plan Rozwoju i Konsolidacji Finansów (Propozycje), Kancelaria Prezesa Rady Ministrów, 29 I 2010.

Prawo o szkolnictwie wyższym z 27 lipca 2005 r., Dz. U. 2005, nr 164, poz. 1365 ze zm., [online] http://isap.sejm.gov.pl/DetailsServlet?id=WDU20051641365.

Strategia rozwoju nauki w Polsce do 2015 r., Biuletyn Informacji Publicznej, [online] http:// www.bip.nauka.gov.pl/_gAllery/20/48/2048/20070629_Strategia_Rozwoju_Nauki_w_ Polsce_do_2015.pdf.

Strategia rozwoju szkolnictwa wyższego 2010-2020. Projekt środowiskowy, [online] http://www. krasp.org.pl/pl/strategia/strategia.

Strategia Rozwoju Szkolnictwa Wyższego do 2020 r., Oficjalna strona internetowa Ministerstwa Nauki i Szkolnictwa Wyższego, [online] http://www.nauka.gov.pl/finansowanie/fundusze-europejskie/program-operacyjny-kapital-ludzki/projekty-systemowe/strategia-rozwoju-sw-do-roku-2020/.

Strategia rozwoju szkolnictwa wyższego: 2010-2020 - Projekt środowiskowy, [online] http:// www.frp.org.pl/pliki/Strategia_tom-1.pdf.

Ustawa o dziataniach administracji rządowej z dnia 4 września 1997, Dz. U. 1997, nr 141, poz. 943, [online] http://isap.sejm.gov.pl/DetailsServlet?id=WDU19971410943.

Ustawa z dnia 12 września 1990 r. o szkolnictwie wyższym, Dz. U. 1990, nr 65, poz. 385, [online] http://isap.sejm.gov.pl/DetailsServlet?id=WDU19900650385.

Ustawa z dnia 12 września 1990 r. o tytule naukowym i stopniach naukowych, Dz. U. 1990, nr 65, poz. 386, [online] http://isap.sejm.gov.pl/DetailsServlet?id=WDU19900650386.

Ustawa z dnia 15 grudnia 1951 r. o szkolnictwie wyższym i o pracownikach nauki, Dz. U. 1952, nr 006, poz. 38, [online] http://isap.sejm.gov.pl/DetailsServlet?id=WDU19520060038.

Ustawa z dnia 20 grudnia 1968 r. o zmianie ustawy o szkolnictwie wyższym, Dz. U. 1968, nr 46, poz. 334, [online] http://isap.sejm.gov.pl/DetailsServlet?id=WDU19680460334.

Ustawa z dnia 26 czerwca 1997 r. o wyższych szkotach zawodowych, Dz. U. 1997, nr 96, poz. 590, [online] http://isap.sejm.gov.pl/DetailsServlet?id=WDU19970960590.

Ustawazdnia26czerwca1997r.owyższychszkotachzawodowych,Dz.U.1997,nr96,poz.590zpóźn. zmianami, [online] http://isap.sejm.gov.pl/DetailsServlet?id=WDU19970960590.

Ustawa z dnia 27 lipca 2005 r. Prawo o szkolnictwie wyższym, Dz. U. 2005, nr 164, poz. 1365, [online] http://isip.sejm.gov.pl/DetailsServlet?id=WDU20051641365.

Ustawa z dnia 4 maja 1982 r. o szkolnictwie wyższym, Dz. U. 1982, nr 14, poz. 113, [online] http://isap.sejm.gov.pl/DetailsServlet?id=WDU19820140113.

Ustawa z dnia 5 listopada 1958 r. o szkotach wyższych, Dz. U. 1958, nr 68, poz. 336, [online] http://isap.sejm.gov.pl/DetailsServlet?id=WDU19580680336.

Ustawa z dnia 8 października 2004 r. o zasadach finansowania nauki, Dz. U. 2004, nr 238, poz. 2390 ze zm., [online] http://isap.sejm.gov.pl/DetailsServlet?id=WDU20042382390.

\section{Literatura pomocnicza:}

- prace zbiorowe:

100 voices. A decade of inspiration and achievements in higher education, UNESCO - European Centre for Higher Education, UNESCO - CEPES, 2009, [online] http://unesdoc.unesco. org/images/0018/001894/189471e.pdf. 
Akredytacja środowiskowa, Portal o jakości w szkolnictwie wyższym, [online] http://www. mea-universitas.pl/akredytacja-srodowiskowa/

Chronologiczny spis ustaw regulujących funkcjonowanie szeroko pojętego szkolnictwa niepublicznego, [online] http://isap.sejm.gov.pl/KeyWordServlet?viewName=thasS\&passName=szkolnictwo\%20niepa\%C5\%84stwowe.

Dane statystyczne o szkolnictwie wyższym Ministerstwa Nauki i Szkolnictwa Wyższego, [online] http://www.nauka.gov.pl/szkolnictwo-wyzsze/dane-statystyczne-o-szkolnictwie-wyzszym/

Diagnoza stanu szkolnictwa wyższego w Polsce. Organizacyjna i merytoryczna koordynacja procesu opracowania projektów sektorowej strategii rozwoju szkolnictwa wyższego w roku 2020, ze szczególnym uwzględnieniem okresu do 2015 roku, Ernst\&Young Business Advisory, Instytut Badań nad Gospodarką Rynkową, listopad 2009.

Dziatalność badawcza i rozwojowa, [online] http://stat.gov.pl/gus/definicje_PLK_HTML. htm?id=POJ-125.htm.

Edufactory - samoorganizacja i opór w fabrykach wiedzy, red. J. Sowa, K. Szadkowski, Kraków 2011.

Edukacja w zarysie 2010: wskaźniki OECD. Podsumowanie w jezyku polskim, [online] http:// www.oecd.org/education/highereducationandadultlearning/45943482.pdf.

Europejskie a Krajowe Ramy Kwalifikacji, [online] http://siloe.slask.pl/e-portfolio/index.php? option $=$ com_content $\&$ view $=$ article $\& i d=53$ : europejskie-a-krajowe-ramy-kwalifikacji $\&$ catid=37:metodyka-eportfolio\&Itemid $=50$

List of OECD Member countries - Ratification of the Convention on the OECD, [online] http:// www.oecd.org/document/58/0,3746,en_2649_201185_1889402_1_1_1_1,00.html.

Nauka i technika w 2006 r., GUS, Warszawa 2007,

Nauka i technika w Polsce w 2009 roku, GUS, Warszawa 2011.

Obszar IV Paktu dla edukacji - Szkolnictwo wyższe i nauka, Związek Nauczycielstwa Polskiego, Warszawa 2011, [online] http://www.znp.edu.pl/element/1156/Pakt_dla_edukacji.

Podstawowy btad atrybucji, [online] http://www.naukowy.pl/encyklo.php?title=Podstawowy_ b\%C5\%82\%C4\%85d_atrybucji.

Proces Boloński. Europejski Obszar Szkolnictwa Wyższego, [online] http://www.uj.edu.pl/documents/10172/22085/proces_bolonski.pdf.

Strategia Polskiej Komisji Akredytacyjnej, [online] http://www.pka.edu.pl/index.php?page=misja. Szkoty wyższe i ich finanse w 2010 r., Główny Urząd Statystyczny, Warszawa 2011, [online] http://www.stat.gov.pl/cps/rde/xbcr/gus/e_szkoly_wyzsze_2010.pdf.

Uczelnia przysztości gwarancja zatrudnienia, [online] http://pkpplewiatan.pl/opinie/stosunki_ pracy/1/uczelnia_przyszlosci_gwarancja_zatrudnienia.

Uwarunkowania przysztego rozwoju szkolnictwa wyższego w Polsce: globalizacja, demografia $i$ zmiany spoteczno-gospodarcze w Polsce. Organizacyjna i merytoryczna koordynacja procesu opracowania projektów sektorowej strategii rozwoju szkolnictwa wyższego do roku 2020, ze szczególnym uwzględnieniem okresu do 2015 roku, Instytut Badań nad Gospodarką Rynkową, Ernst\&Young Business Advisory, 2009, [online] http://www.nauka.gov.pl/ fileadmin/user_upload/Finansowanie/fundusze_europejskie/PO_KL/Projekty_systemowe/20100727_Etap_2_uwarunkowania_rozwoju_SW_globalizacja_demografia_i_ zmiany.pdf. 
Uwarunkowania rozwoju szkolnictwa wyższego: prawo, finanse publiczne, czynniki kulturowe, przygotowanie absolwentów, Ernst\&Young Business Advisory, Instytut Badań nad Gospodarką Rynkową, listopad 2009, [online] http://www.nauka.gov.pl/fileadmin/user upload/Finansowanie/fundusze_europejskie/PO_KL/Projekty_systemowe/20100727_ Etap_2_uwarunkowania_rozwoju_SW_prawo_finanse_publiczne_czynniki_kulturowe_przygotowanie_absolwentow.pdf.

What Is the Impact of Demography on Higher Education Systems? A Froward-looking Approach for OECD Countries, OECD, 2008, [online] https://www1.oecd.org/edu/ceri/41939423.pdf.

Wspótczynnik skolaryzacji - szkolnictwo wyższe, [online] http://www.studenckamarka.pl/serwis.php? $=73 \&$ pok $=1922$.

Zakres dziatania RGNiSW, [online] http://www.rgnisw.nauka.gov.pl/?q=node/657.

Zatożenia do aktów prawnych dotyczacych nauki, szkolnictwa wyższego i dziatalności badawczo rozwojowej (opracowanie z grudnia 1989), „Nauka Polska. Jej potrzeby, organizacja i rozwój” 1993.

Zatożenia do nowelizacji ustawy - Prawo o szkolnictwie wyżsym oraz ustawy o stopniach naukowych i tytule naukowym oraz o stopniach i tytule $w$ zakresie sztuki, Biuletyn Informacji Publicznej, [online] http://www.bip.nauka.gov.pl/_gAllery/69/70/6970/20091019_ Zalozenia_do_nowelizacji_ustawy.pdf.

\section{- rozdziały w pracach zbiorowych:}

Finansowanie uczelni publicznych, [w:] Zatożenia do nowelizacji ustawy-Prawo o szkolnictwie wyżsym oraz ustawy o stopniach naukowych i tytule naukowym oraz o stopniach i tytule $w z a-$ kresie sztuki, Biuletyn Informacji Publicznej, [online] http://www.bip.nauka.gov.pl/_gAllery/69/70/6970/20091019_Zalozenia_do_nowelizacji_ustawy.pdf.

\section{- artykuły prasowe:}

Bielski M., Nie akt, lecz proces, [online] http://forumakad.pl/archiwum/2001/11/artykuly/06-sem_forum.htm.

E-learning - dobry patent na produkcje bezrobotnych, [online] http://serwisy.gazetaprawna.pl/ praca-i-kariera/galerie/553495,zdjecie,1,e_learning_dobry_patent_na_produkcje_bezrobotnych.html.

Macukow B., Akredytacja i jakość, [online] http://forumakademickie.pl/fa/2011/11/akredytacja-i-jakosc/.

Potowa studentów krytycznie ocenia kompetencje zdobyte na studiach, 20 VII 2012, http://www. naukawpolsce.pap.pl/aktualnosci/news,390982, polowa-studentow-krytycznie-ocenia-kompetencje-zdobyte-na-studiach.html.

Rozmus A., Pado K., Finansowanie szkolnictwa wyższego w Polsce - wybrane dylematy i sugerowane rozwiazania, „E-finanse - finansowy kwartalnik internetowy” 2011, nr 114, [online] http://www.e-finanse.com/artykuly_eng/114.pdf.

\section{Strony internetowe:}

http://stat.gov.pl/bdl/app/dane_podgrup.display?p_id=736791\&p_token=0.552855125861242 http://uka.amu.edu.pl/uka_main.php.

http://www.fundacja.edu.pl/. 
http://www.kaaum.pl/.

http://www.kaut.agh.edu.pl/.

http://www.krajoweramykwalifikacji.pl/index.php?id=krk.

Magdalena RACZYŃSKA - studentka III roku studiów I stopnia na kierunku stosunki międzynarodowe w Instytucie Nauk Politycznych i Stosunków Międzynarodowych Uniwersytetu Jagiellońskiego. W latach 2011-2012 członek Zarządu Koła Studentów Stosunków Międzynarodowych Uniwersytetu Jagiellońskiego ds. promocji i kontaktów zewnętrznych. Od kwietnia 2012 r. Sekretarz KSSM UJ. Ponadto Sekretarz redakcji czasopisma „Poliarchia. Studenckie Zeszyty Naukowe Wydziału Studiów Międzynarodowych i Politycznych Uniwersytetu Jagiellońskiego.” Współautorka publikacji „Podsumowanie polskiej prezydencji w Radzie UE” (Kraków 2012). Publikowała w magazynie opinii „ARENA. Sprawy międzynarodowe”. Zainteresowania naukowe: dyplomacja współczesna, public relations w stosunkach międzynarodowych, organizacja i zarządzanie w biznesie. 